*akls View/Frint Document Cover Sheet tow

This document was retrieved from the Boeing ISEARCH System.

Accession \#: D196054541

Document \#: SD-WM-ER-425

Title/Desc:

TANK 241C111 HEADSPACE GAS \& VAPOR CHARACTERIZATION RESULTS FOR SAMPLES COLLECTED IN $8 / 1993 \& 9 / 1994$ 


\section{ENGINEERING CHANGE NOTICE}

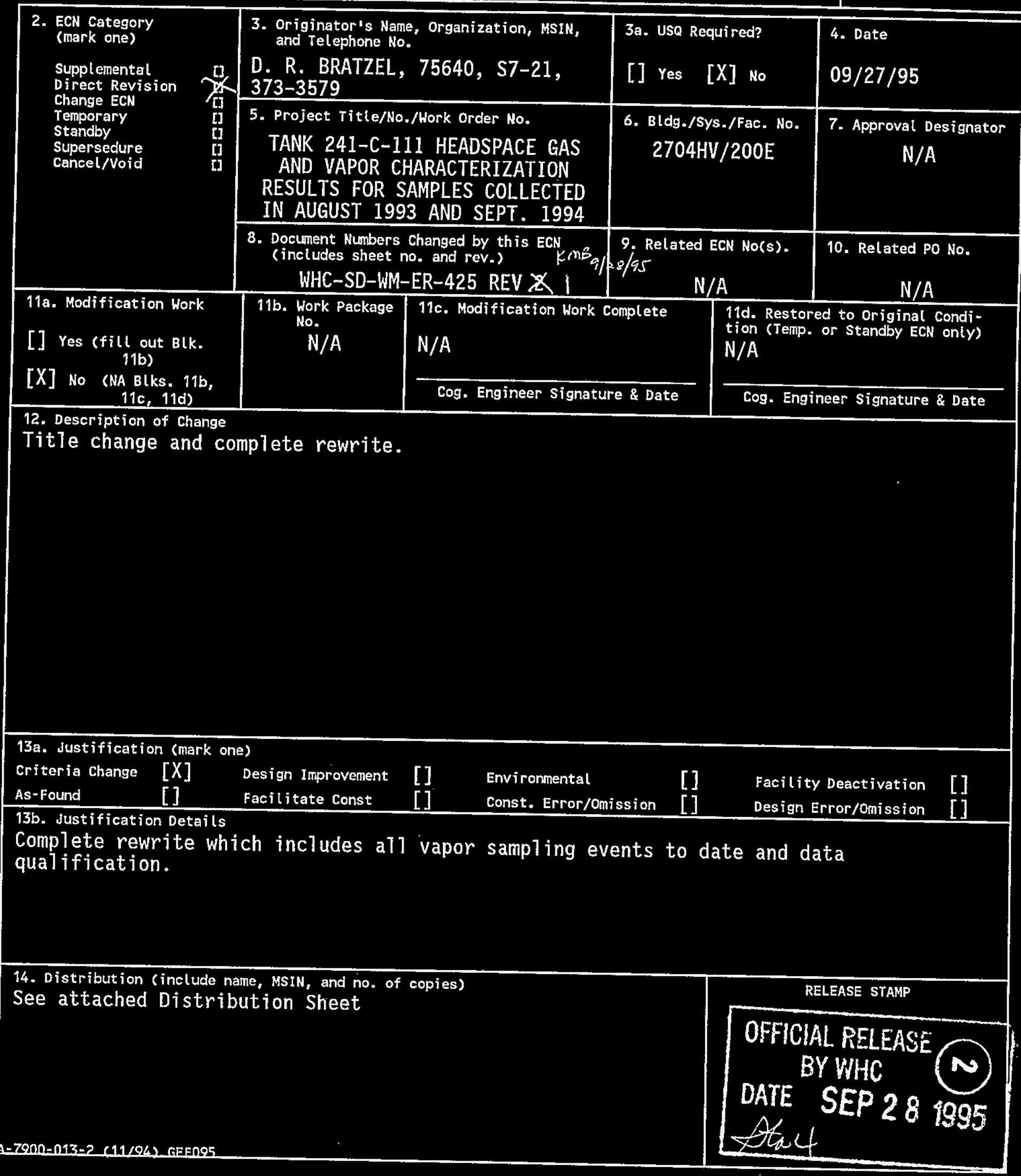

3. Originator's Name, Organization, MSIN, and Telephone No.

\section{Proj.}

ECN 


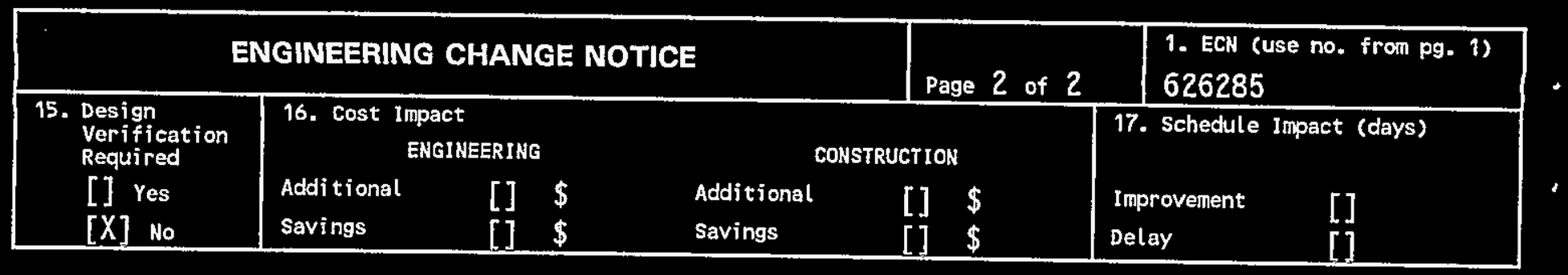

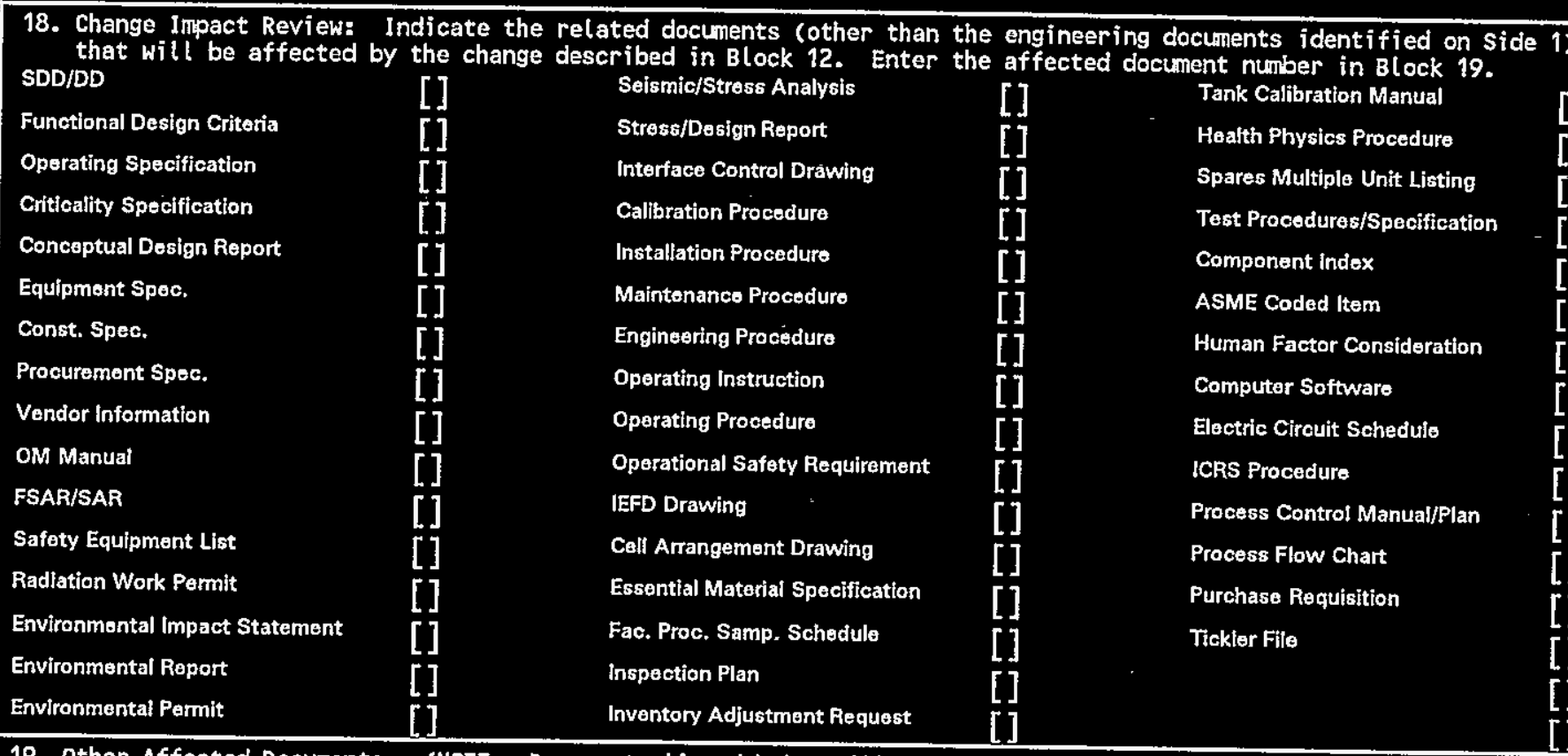

19. Other Affected Documents: (NOTE: Documents listed below will not be revised by this ECN.) Signatures below indicate that the signing organization has been notified of other affected documents listed below. Document Number/Revision

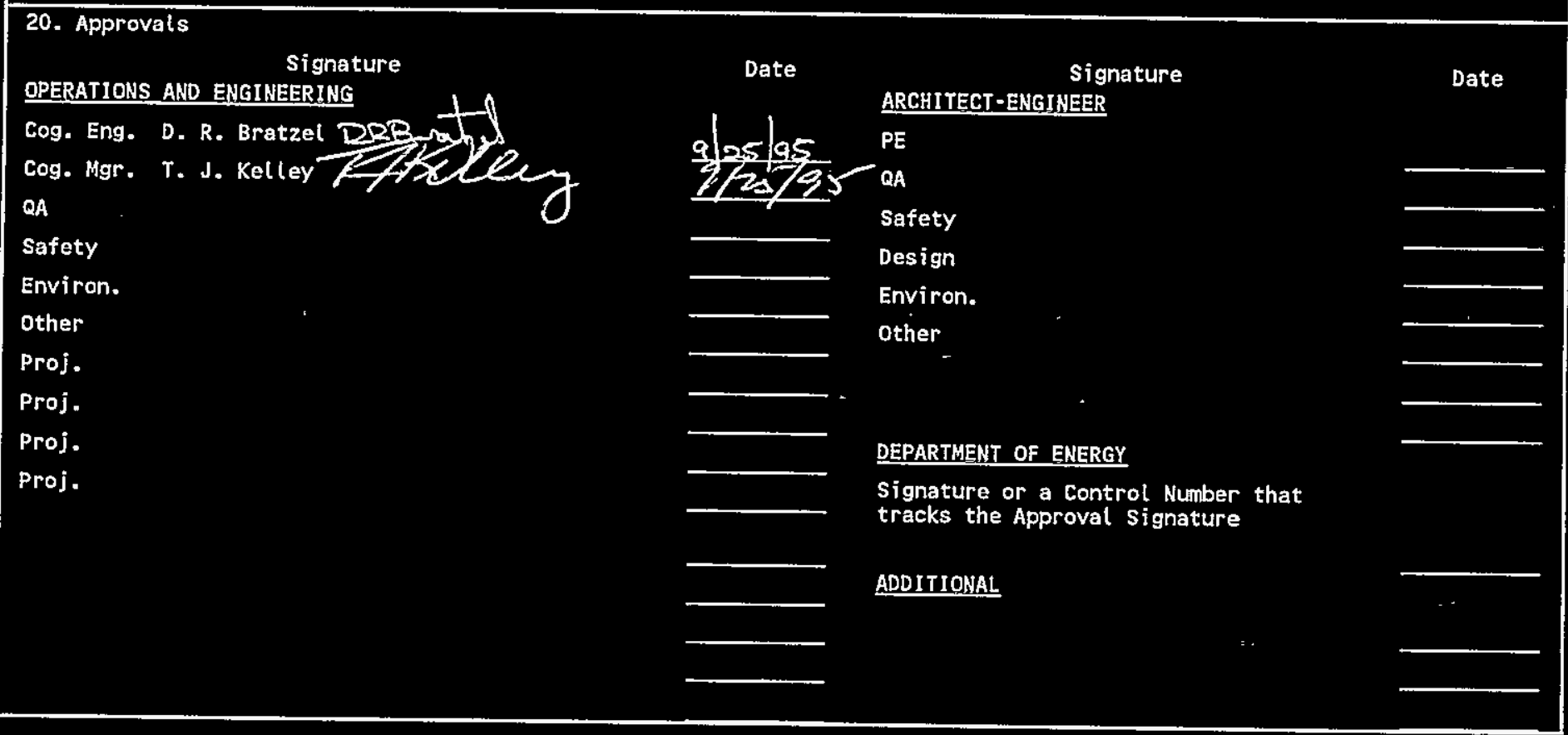




\section{RELEASE AUTHORIZATION}

Document Number: WHC-SD-WM-ER-425, REV 2

Document Title:

Tank 241-C-111 Headspace Gas and Vapor

Characterization Results for Samples Collected in

August 1993 and September 1994

Release Date: $\quad 9 / 28 / 95$

This document was reviewed following the
procedures described in WHC-CM-3-4 and is:

APPROVED FOR PUBLIC RELEASE

WHC Information Release Administration Specialist:
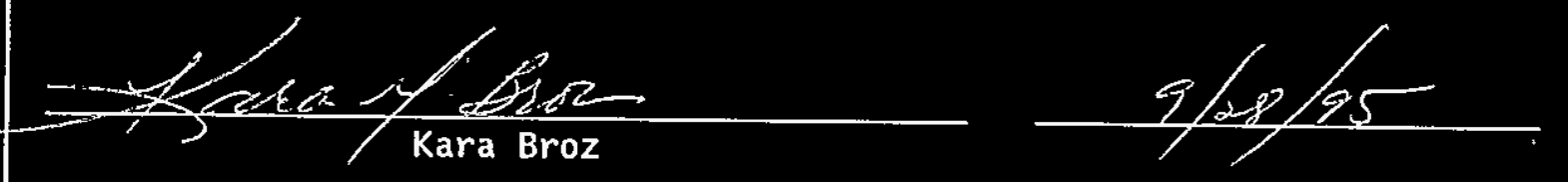

TRADEMARK DISCLAIHER. Reference herein to any specific commercial product, process, or service by trade name, trademark, manufacturer, or otherwise, does not necessarily constitute or imply its endorsement, recommendation, or favoring by the United States Government or any agency thereof or its contractors or subcontractors.

This report has been reproduced from the best available copy. Available in paper copy. Printed in the United States of America. To obtain copies of this report, contact:

Westinghouse Hanford Company - Document Control Services

P.0. Box 1970, Mailstop H6-08, Richland, WA 99352

Telephone: (509) 372-2420; Fax: (509) 376-4989 


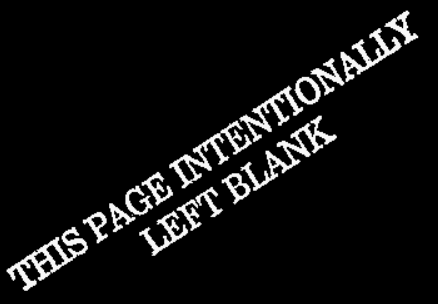




\section{SUPPORTING DOCUMENT}

1. Total pages 38

\begin{tabular}{|c|c|}
\hline $\begin{array}{l}\text { 2. Title } \\
\text { TANK 241-C-111 HEADSPACE GAS AND VAPOR } \\
\text { CHARACTERIZATION RESULTS FOR SAMPLES COLLECTED IN } \\
\text { AUGUST } 1993 \text { AND SEPTEMBER } 1994\end{array}$ & $\begin{array}{l}\text { 3. Nunber } \\
\text { HHC-SB-HM-ER-425 }\end{array}$ \\
\hline $\begin{array}{l}\text { 5. Key Words } \\
\text { CHARACTERIZATION OBJECTIVES, TANK HEADSPACE, } \\
\text { SAMPLING EVENT, INORGANIC GASES, ORGANIC VAPORS }\end{array}$ & $\begin{array}{l}\text { 6. Author } \\
\text { Name: D. R. BRATZEL } \\
\text { signature } \\
\text { organization/Charge code } 75640 / \mathrm{N} 4 \mathrm{AB}\end{array}$ \\
\hline
\end{tabular}

7. Abstract

Significant changes have been made to all of the original vapor characterization reports. This report documents specific headspace gas and vapor characterization results for all vapor sampling events to date. In addition, changes have been made to the original vapor reports to qualify the data based on quality assurance issues associated with the performing laboratories. 



\begin{tabular}{|c|c|c|c|c|}
\hline \multicolumn{2}{|r|}{ RECORD OF REVISION } & \multicolumn{2}{|c|}{$\begin{array}{l}\text { (1) Document Number } \\
\text { WHC-SD-WM-ER-425 }\end{array}$} & Page 1 \\
\hline \multicolumn{5}{|c|}{$\begin{array}{l}\text { (2) Titte } \\
\text { TANK 241-C-111 HEADSPACE GAS AND VAPOR CHARACTERIZATION RESULTS FOR SAMPLES COLLECTED } \\
\text { IN AUGUST } 1993 \text { AND SEPTEMBER } 1994\end{array}$} \\
\hline \multicolumn{5}{|c|}{ CHANGE CONTROL RECORD } \\
\hline (3) Revision & (4) Description of Change - Replace, Add, and Delete Pages & \multicolumn{3}{|c|}{ Authorized for Release } \\
\hline 0 & $\begin{array}{l}\text { (7) WHC-SD-WM-ER-425, REV. 0, EDT } 612086 \\
\text { May } 31,1995\end{array}$ & (5) Cog. Engr. & (6) 0 & Date \\
\hline 1 & $\begin{array}{l}\text { Made editorial changes and added } \\
\text { information in organic vapor chapter. ECN } \\
623548\end{array}$ & & & \\
\hline RF 2 & $\begin{array}{l}\text { Complete revision and title change. ECN } \\
626285\end{array}$ & & & \\
\hline & & & & $\sigma$ \\
\hline & & & & \\
\hline & & & & \\
\hline & & & & \\
\hline & & & & \\
\hline & & & & \\
\hline & & & & \\
\hline & & & & \\
\hline & & & & \\
\hline & & & & \\
\hline & & & & \\
\hline & & & & \\
\hline
\end{tabular}


B 


\title{
Tank 241-C-111 Headspace Gas and Vapor Characterization Results for Samples Collected in August 1993 and September 1994
}

\author{
J. L. Huckaby \\ Pacific Northwest Laboratories \\ D. R. Bratzel \\ Westinghouse Hanford Company
}

Date Published

September 1995

Prepared for the U.S. Department of Energy Office of Environmental Restoration and Waste Management 
$\not$ 


\section{Contents}

1.0 INTRODUCTION

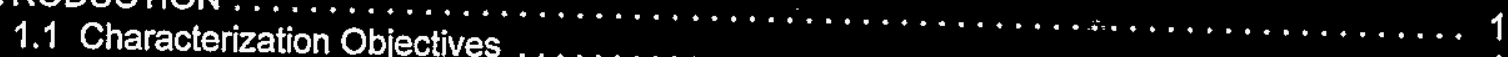

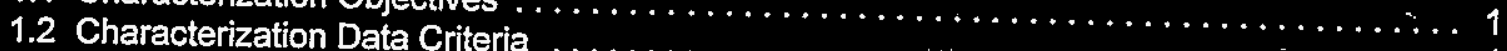

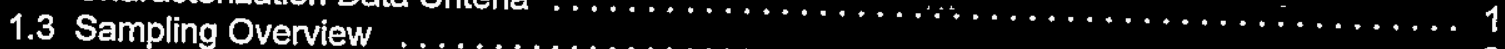

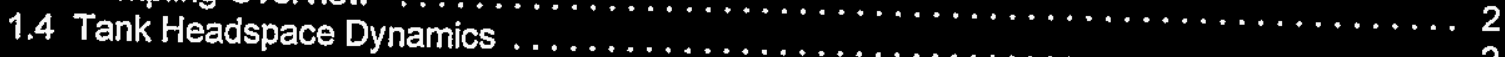

2.0 SAMPLING EVENT

2.1 August 1993 In Situ Sampling Event ............................ 4

2.2 September 1994 Vapor Sampling System Sampling Event $\ldots \ldots \ldots \ldots \ldots \ldots \ldots \ldots \ldots$

3.0 INORGANIC GASES AND VAPORS

3.1 Ammonia, Hydrogen, and Nitrous Oxide $\ldots \ldots \ldots \ldots \ldots \ldots \ldots \ldots \ldots \ldots \ldots \ldots \ldots \ldots \ldots \ldots \ldots \ldots \ldots \ldots \ldots$

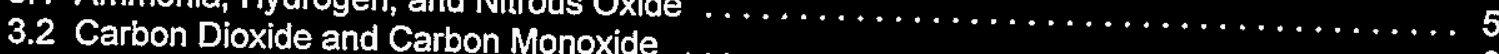

3.3 Nitric Oxide, Nitrogen Dioxide, Water and Tritium $\ldots \ldots \ldots \ldots \ldots \ldots \ldots \ldots \ldots \ldots \ldots \ldots \ldots \ldots \ldots \ldots \ldots \ldots$

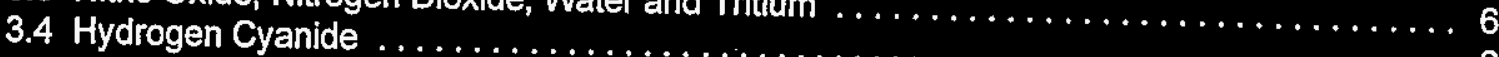

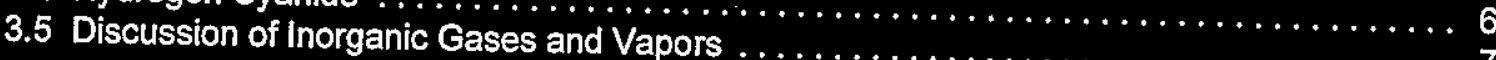

4.0 ORGANIC VAPORS $\ldots \ldots \ldots \ldots \ldots \ldots \ldots \ldots \ldots \ldots \ldots \ldots \ldots \ldots \ldots \ldots \ldots \ldots \ldots \ldots$
4.1 Positively Identified Organic Analytes $\ldots \ldots \ldots \ldots \ldots \ldots$

4.1 Positively ldentified Organic Analytes $\ldots \ldots \ldots \ldots \ldots \ldots \ldots \ldots \ldots \ldots \ldots \ldots \ldots \ldots, \ldots \ldots \ldots$

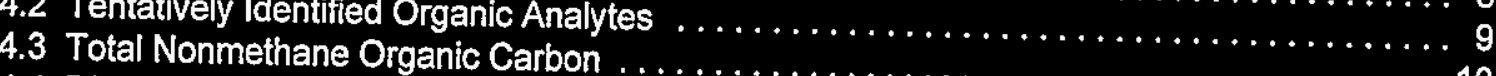

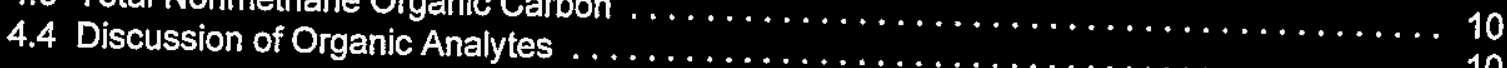

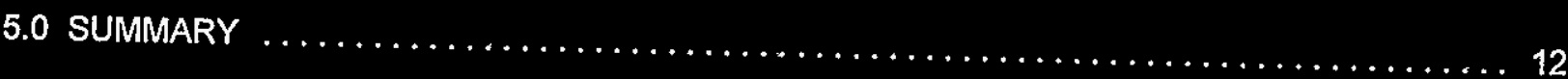

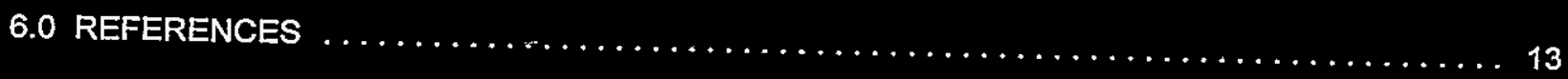

Acronyms and Abbreviations

CES

EPA

GC

GC/MS

ISS

LFL

MS

NFPA

NPH

OGIST

ORNL

PNL

ppmv

TNMOC

TST

vol\%

VSS

WHC consensus exposure standard

Environmental Protection Agency

gas chromatograph

gas chromatograph/mass spectrometer

in situ sampling

lower flammability limit

mass spectrometer

National Fire Protection Association

normal paraffinic hydrocarbon

Oregon Graduate Institute of Science and Technology

Oak Ridge National Laboratory

Pacific Northwest Laboratory

parts per million by volume, 1 ppmv $=10^{-4}$ vol $\%$

total nonmethane organic carbon

triple sorbent trap

percent by volume, 1 vol $\%=10,000$ ppmv

vapor sampling system

Westinghouse Hanford Company 


\section{WHC-SD-WM-ER-425 REV. 2}

\section{Acknowledgements}

The authors wish to thank Chris Simonen for her work verifying data and generating tables, and Shas Mattigod for his help with the construction and reviews of this document. The authors also wish to thank Luther Buckley, Clarence Homi, and Tom Kunthara for their contributions to the final reviews and publication of this document. 
WHC-SD-WM-ER-425 REV. 2

Tank 241-C-111 Headspace Gas and Vapor Characterization Results

for Samples Collected in August 1993 and September 1994

\subsection{INTRODUCTION}

\subsection{Characterization Objectives}

Tank C-111 headspace gas and vapor samples were collected and analyzed to help determine the potential risks of fugitive emissions to tank farm workers. The drivers and objectives of waste tank headspace sampling and analysis are discussed in Program Plan for the Resolution of Tank Vapor Issues (Osborne and Huckaby 1994). This report primarily discusses results from the September 1994 sampling event, but also includes selected results of the August 1993 sampling event. The tank $\mathrm{C}-111$ headspace was sampled in August 1993 to address concerns about hydrogen cyanide fugitive emissions from the waste tanks (Saget 1992), and in September 1994 in accordance with Data Quality Objectives for Generic In-Tank Health and Safety Issue Resolution (Osborne et al. 1994).

\subsection{Characterization Data Criteria}

Data Quality Objectives for Generic In-Tank Health and Safety Issue Resolution describes parameters for data collection to ensure appropriate conclusions can be drawn from the data. Tank headspace characterization data were collected to help in the evaluation of 1) headspace flammability, and 2) identification and quantification of compounds of toxicological concern.

Single Shell Tank Interim Operational Safety Requirements (Dougherty 1995) specifies that combustible constituents in tank headspaces be maintained below $25 \%$ of the lower flammability limit (LFL). This essentially agrees with National Fire Protection Association requirements that combustible concentrations be maintained at or below $25 \%$ of the LFL (NFPA 1992). Current governing operating specifications for Watchlist tanks, such as tank C-108, specify that combustible constituents be maintained at or below $20 \%$ of the LFL (WHC 1995a).

Headspace characterization data are used by Westinghouse Hanford Company (WHC) Tank Waste Remediation Systems Industrial Hygiene as source term data in the industrial hygiene strategy to protect workers from tank fugitive emissions. Because selection of worker protective equipment must be based on industrial hygiene monitoring of the work place and not on source term data (29 CFR 1910.120), tank headispace characterization data can not be used for this purpose. Furthermore, because there are mechanisms by which headspace constituents can be either diluted or concentrated as they are released to the atmosphere, the headspace characterization data should not be considered to be representative of emissions at the point of emission.

These statements notwithstanding, the data quality objectives document specifies that the industrial hygiene group be advised if constituents with toxicological properties exceed $50 \%$ of the appropriate consensus exposure standard (CES) for non-carcinogens, or $10 \%$ of the appropriate CES for carcinogens. A CES is defined as the most stringent of known regulatory or recommended toxicological values for the workplace (Osborne et al. 1994). 
WHC-SD-WM-ER-425 REV. 2

\subsection{Sampling Overview}

Tank C-111 was vapor sampled in August 1993 and June 1994 using in situ sampling (ISS) methods. In the August 1993 sampling event, liquid-illed bubblers were lowered into the tank headspace to sample for hydrogen cyanide. The second ISS event, in June 1994, was performed as required by Safety

Assessment for Gas Sampling All Ferrocyanide Tanks (Farley 1991). Tank C-111 was sampled again in September 1994 using the more robust Vapor Sampling System (VSS). Because the ISS sample volume flow measurement used during both the August 1993 and June 1994 events was inherently less accurate than that of the VSS, the sorbent trap samples from the ISS event are not considered to be equivalent to those from the VSS sampling event (Huckaby and Babad 1995). Furthermore, there are other discrepancies between results from the ISS and VSS methods that are not understood (Huckaby 1994a), and until the ISS method has been validated and the discrepancies resolved, results from early isS events should be considered suspect.

Nevertheless, a brief description of the August 1993 ISS event and the results of the hydrogen cyanide sampling are presented below, because this analyte was not sampled for during the VSS event. Huckaby and Babad (1995) describe the bases for using the ISS method for hydrogen cyanide, and why it was not sampled for during the VSS event. Also, samples from the September 1994 VSS sampling event were not analyzed for carbon monoxide, so results presented below for this compound are from the August 1993 ISS event. All other results presented here are from the August 1994 VSS sampling event.

Pingel (1995) describes the June 1994 ISS event, Mahon (1995) provides revised sample volume measurements, and Ligotke et al. (1995) describe sample preparation, analyses, and results. This sampling event and its results are not discussed further here.

Samples collected are thought to have been representative of the tank C-111 headspace when the tank was sampled, and sample analyses were designed to provide a reasonably accurate and complete characterization of the significant headspace constituents (Meacham et al. 1995). During the August 1993 ISS event, samples collected from 3 different elevations within the headspace were measured to contain essentially identical concentrations of hydrogen, carbon monoxide, methane, nitrous oxide, and organic vapors (Huckaby 1994b). Though no assessment has been made of how the tank C-111 headspace composition changes with time, the August 1993 ISS data, June 1994 ISS data, and September 1994 VSS agree reasonably well. Studies of tank C-103 suggest that composition changes probably occur very slowly in the passively ventilated tanks (Huckaby and Story 1994).

\subsection{Tank Headspace Dynamics}

Tank $\mathrm{C}-111$ is the second tank in a 3-tank cascade with tanks $\mathrm{C}-110$ and $\mathrm{C}-112$, and is connected to tank C-110 (the first tank in the series) via a 7.4-cm (2.9-in.) inside diameter, 7.6-m (25- $\mathrm{ft}$ ) long underground cascade line. Tank $\mathrm{C}-111$ is also connected with tank $\mathrm{C}-112$ by a similar cascade line. Since these cascade lines connect the headspaces of these tanks, gases and vapors originating from the wastes in tank $\mathrm{C}-110$ or tank C-112 may be transferred to tank $\mathrm{C}-111$ (unless the cascade lines are obstructed). However, headspace data, as discussed in Section 3.5, indicate that the inter-tank exchange of gases and vapors probably has little effect on the headspace composition of tank C-111.

The cascade of tanks $\mathrm{C}-110, \mathrm{C}-111$, and $\mathrm{C}-112$ is passively ventilated, which means that the tanks are allowed to exhale air, waste gases, and vapors as the barometric pressure falls, and inhale ambient air as the barometric pressure rises. Each of these tanks has its own filtered breather riser. Barometric 


\section{WHC-SD-WM-ER-425 REV. 2}

pressure typically rises and falls on a diurnal cycle, producing an average daily exchange of air equal to headspace constituents due to barometric $0.46 \%$ of each tank headspace (Huckaby). Changes in the concentrations of tank

headspace constituents due to barometric pressure changes are consequently very slow. 


\subsection{SAMPLING EVENT}

\subsection{August 1993 In Situ Sampling Event}

Tank C-111 was sampled using ISS methods on August 10, 1993 by WHC Sampling and Mobile Laboratories. This sampling was conducted to address concerns that ferrocyanide Watch List tanks could be releasing hydrogen cyanide vapors into the breathing zone of tank farm workers (Saget 1992). Three hydrogen cyanide samples were collected from a point approximately $7.5 \mathrm{~m}$ below the top of the flange on riser 6 , between 10:30 a.m. and 12:00 noon.

Huckaby and Babad (1995) give a general description of the ISS method and equipment. Pingel (1993) provides field sampling information for the tank C-111 June 1993 ISS event. In addition to the hydrogen cyanide results presented below, Huckaby (1994b) discusses sample devices, sample collection, and tabulates results for selected organic and inorganic species.

\subsection{September 1994 Vapor Sampling System Sampling Event}

Headspace gas and vapor samples were collected from tank C-111 using the vapor sampling system (VSS) on September 13, 1994 by WHC Sampling and Mobile Laboratories (WHC 1995). Sample collection and analysis were performed as directed by the sample and analysis plan ${ }^{1}$ (WHC 1995b, Appendix A). The tank headspace temperature was determined to be $27^{\circ} \mathrm{C}$. Air from the tank $\mathrm{C}-111$ headspace was withdrawn via a $7.9 \mathrm{~m}$-long heated sampling probe mounted in riser 6 , and transferred via heated tubing to the VSS sampling manifold. All heated zones of the VSS were maintained at approximately $50^{\circ} \mathrm{C}$.

Sampling media were prepared and analyzed by WHC, Oak Ridge National Laboratories (ORNL), Pacific Northwest Laboratories (PNL), and Oregon Graduate Institute of Science and Technology (OGIST) through a contract with Sandia National Laboratories (SNL). The 39 tank air samples and 2 ambient air control samples collected are listed in Table 2-1 by analytical laboratory. Table 2-1 also lists the 14 trip blanks provided by the laboratories.

A general description of vapor sampling and sample analysis methods is given by Huckaby and Babad (1995). The sampling equipment, sample collection sequence, sorbent trap sample air flow rates and flow times, chain of custody information, and a discussion of the sampling event itself are given in WHC $1995 \mathrm{~b}$.

\footnotetext{
The current requirement that sampling and analysis parameters be specified by a tank characterization plan was not in effect for gas and vapor sampling until October $1,1994$.
} 


\subsection{INORGANIC GASES AND VAPORS}

Analytical results of sorbent trap and SUMMA ${ }^{\mathrm{TM}, 2}$ canister tank air samples for selected inorganic gases and vapors are given in Table 3-1 in parts per million by volume (ppmv) in dry air. The concentration of water vapor given in Table 3-1 has been adjusted to tank conditions as given in Section 3.3. Inorganic analyte sorbent traps were prepared and analyzed by PNL, and SUMMA ${ }^{\text {TM }}$ canister samples were prepared and analyzed for inorganic gases and vapors by OGIST. Reports by Lucke et al. (1995) and Rasmussen (1994) describe sample preparation and analyses for the September 1994 VSS sampling event, and Lerner and Pool (1994) describe the preparation and analyses of hydrogen cyanide samples collected during the August 1993 iss event.

All PNL results were produced at PNL quality assurance impact level 3. PNL analyses of sorbent traps for inorganic compounds from the September 1994 VSS event were performed 13 days after sample collection (Ligotke 1995), which was within the 60-day holding time requirement of the WHC quality assurance project plan (Keller 1994). The 60-day holding time was administratively chosen, and no holding time study has been done to address the stability of analytes in sorbent traps or SUMMA ${ }^{\text {TM }}$ canisters in the chemical matrix of tank samples. PNL analyses of the ISS hydrogen cyanide samples were completed 41 days after these samples were collected.

OCIST SUMMA ${ }^{\mathrm{TM}}$ canister analyses were started 14 days after the samples were collected (Rasmussen 1994). OGIST was not operating under a WHC-approved quality assurance plan when samples were analyzed, and OGIST data have been placed in square brackets both in Table 3-1 and elsewhere in this report to indicate that they represent secondary results.

\subsection{Ammonia, Hydrogen, and Nitrous Oxide}

The reported ammonia concentration in the tank $\mathrm{C}-111$ headspace was measured to be $5.6 \mathrm{ppmv}$. Ammonia concentrations in the waste tank headspaces have typically been observed to be higher than this level. The relatively low ammonia concentration in tank $\mathrm{C}-111$ may be related to the fact that only a small quantity of relatively cool waste is stored in tank C-111. Given the LFL of ammonia in air is about 15 $\%$ by volume (vol\%), the measured 5.6 ppmv corresponds to about $0.004 \%$ of the LFL, and does not contribute appreciably to the flammability of the headspace.

Hydrogen was measured to be an average of [12.4 ppmv] in the 3 SUMMA ${ }^{\mathrm{TM}}$ canisters analyzed by OGIST. In general, hydrogen is of concern as a fuel. Given the LFL for hydrogen in air is about 4 vol\%, the [12.4 ppmv] of hydrogen in tank C-111, corresponds to only about $0.03 \%$ of the $L F L$, and is not a concern.

The average nitrous oxide in SUMMA ${ }^{\text {TM }}$ samples from tank C-111 was [99.3 ppmv]. This is a typical nitrous oxide concentration for the passively ventilated tanks that have been sampled. Under the proper conditions, nitrous oxide can serve as an oxidizer to support combustion. However, Cashdollar et al. (1992) found that nitrous oxide had no significant effect on the flammability of hydrogen and air mixtures for hydrogen concentrations less than $20 \mathrm{vol} \%$, and that "small amounts of nitrous oxide (relative to air) do not appear to have much effect on the flammability". Their results suggest the measured nitrous oxide concentration is much too low to have a significant effect on the flammability of the tank $\mathrm{C}-111$ headspace.

2 SUMMA is a trademark of Molectrics, Inc., Cleveland, Ohio. 


\subsection{Carbon Dioxide and Carbon Monoxide}

The average measured headspace carbon dioxide concentration, [198 ppmv], is significantly below the normal ambient air concentration of about 350 to 400 ppmv. Though some carbon dioxide may be produced by the waste, the primary source of carbon dioxide in most waste tank headspaces is the atmosphere. Carbon dioxide introduced by air exchange with the atmosphere is readily absorbed by caustic supernatant and interstitial liquids of the waste tanks, and converted to carbonate in solution. The level of carbon dioxide in a tank headspace depends on the tank's breathing rate, and the pH and surface area of aqueous waste (i.e., supernate, interstitial liquid, and condensate) in the tank. Though higher than average, the carbon dioxide concentration in tank $\mathrm{C}-111$ appears to be normal.

Carbon monoxide in the tank C-111 headspace, at about [0.10 ppmv], is about normal for ambient air, where it typically ranges from 0.05 to $0.15 \mathrm{ppmv}$. This is the average measurement of 9 SUMMA ${ }^{\mathrm{TM}}$ canister samples collected from tank C-111 during the August 1993 ISS event (Huckaby 1994b). Though carbon monoxide has been measured at above ambient air levels in several tanks, the level of carbon monoxide in tank C-111 is apparently not significant.

\subsection{Nitric Oxide, Nitrogen Dioxide, Water and Tritium}

Nitric oxide and nitrogen dioxide concentrations in the tank $\mathrm{C}-111$ headspace were determined to be 0.62 ppmv and $\leq 0.08$ ppmv, respectively. These are both acid gases that would have very low equilibrium concentrations above the high pH sludge in tank $\mathrm{C}-111$. The measurable presence of nitric oxide may be due to its formation from oxygen and nitrogen in the radiation field of the headspace. These constituents could potentially serve as oxidizers to support combustion, but at the measured concentrations would have a negligible effect on the flammability of the tank $\mathrm{C}-111$ headspace.

The water vapor concentration of tank $\mathrm{C}-111$ was determined to be about $22.2 \mathrm{mg} / \mathrm{L}$, at the tank headspace temperature of $27^{\circ} \mathrm{C}$ and pressure of $988 \mathrm{mbar}$ (741 torr), (WHC 1995b). This corresponds to water vapor partial pressure of $30.72 \mathrm{mbar}$ (23.1 torr), to a dew point of $24.5^{\circ} \mathrm{C}$, and to a relative humidity of $86 \%$.

Tritium was tested for using silica gel sorbent traps. It is assumed that tritium produced by the waste combines with hydroxide ions to form tritium-substituted water. Evaporation of the tritium-substituted water would then result in airborne radioactive contamination. Silica gel sorbent traps adsorb virtually all (normal and tritium-substituted) water vapor from the sampled tank air, and are analyzed at the WHC 222$\mathrm{S}$ laboratory. Analysis of the silica gel indicated the total activity of the headspace to be below $50 \mathrm{pCi} / \mathrm{L}$ (WHC 1995b).

\subsection{Hydrogen Cyanide}

Analysis of the liquid-filled bubblers for hydrogen cyanide indicated the concentration of this analyte to be below $0.00004 \mathrm{ppmv}$ in all 3 samples (Lemer and Pool 1994). The absence of hydrogen cyanide at measurable concentrations is consistent with the expectation that an acid gas, such as hydrogen cyanide, would not exist at significant concentrations above the caustic waste in tank $\mathrm{C}-111$. No hydrogen cyanide has been detected in any of the 10 waste tank headspaces sampled for this analyte. 


\subsection{Discussion of Inorganic Gases and Vapors}

Aside from water vapor and carbon dioxide, the most abundant waste constituents in the tank $\mathrm{C}-111$ headspace are nitrous oxide, hydrogen, and ammonia. These have been detected in most tank headspaces sampled to date, and are usually the dominant gas species. Compared to other passively ventilated waste tanks that have been sampled, tank $\mathrm{C}-111$ has low concentrations of both hydrogen and ammonia.

The relative standard deviations of the inorganic gas and vapor results given in the last column in Table 31 are good for the methods used at the concentrations reported. Relative standard deviations range from less than $1 \%$ for the OGIST measurement of carbon dioxide, to about $16 \%$ for ammonia and hydrogen. Because the precision reported depends both on sampling parameters (e.g., sample flow rate and flow time for sorbent traps) and analytical parameters (e.g., sample preparation, dilutions, etc.), small relative standard deviations suggest proper control was maintained both in the field and in the laboratories.

As discussed briefly in Section 1.0, it is possible that gases and vapors generated by the waste in tanks C110 and $\mathrm{C}-112$ could be transferred to tank $\mathrm{C}-111$ via the cascade lines. Table $3-2$ lists the concentrations of selected inorganic gases and vapors in tanks $\mathrm{C}-110, \mathrm{C}-111$, and $\mathrm{C}-112$. If a significant exchange of gases and vapors were taking place between adjacent tanks, either the headspace compositions of those tanks would be very similar, or all waste constituents detected in one tank would be at equal or higher concentration (and carbon dioxide would be at a lower concentration) in the other tank. Data in Table 3-2 are consistent with the premise that air, gases, and vapors from tank C-111 could be flowing into tank $\mathrm{C}-112$, but do not constitute proof that this indeed is occurring. 
WHC-SD-WM-ER-425 REV. 2

\subsection{ORGANIC VAPORS}

Organic vapors in the tank C-111 headspace were sampled using SUMMA ${ }^{\text {TM }}$ canisters, which were analyzed at PNL and OGIST, and triple sorbent traps (TSTs), which were analyzed by ORNL. PNL, and ORNL used a gas chromatograph (GC) equipped with a mass spectrometer (MS) to separate, identify, and quantitate the analytes. Methane and total nonmethane organic carbon (TNMOC) concentrations were measured by OGIST using GCs with flame ionization detectors. Descriptions of sample device cleaning, sample preparations, and analyses are given by Jenkins et al. (1994), Lucke et al. (1995), and Rasmussen (1994).

SUMMA ${ }^{T M}$ sample results should be considered to be the primary organic vapor data for tank C-111. PNL results were produced at PNL quality assurance impact level 3 . PNL analyses of organic vapors were completed 56 days after sample collection, and within the administratively chosen 60-day holding time (Keller 1994). No holding time study has been performed to determine the stability of analytes in SUMMA ${ }^{\text {TM }}$ canisters in the chemical matrix of the tank samples.

ORNL analyses of TST samples from this and other waste tanks generally agree with, support, and augment the SUMMA ${ }^{\mathrm{TM}}$ sample results. However, because certain WHC quality assurance requirements were not satisfied by ORNL, the quality assurance assessment of ORNL by Hendrickson (1995) should be reviewed before results unique to the TST samples are used for decision making.

All TSTs prepared by ORNL had 3 surrogate compounds added to evaluate sample matrix effects, potential handling, storage, and shipment problems, and analytical instrumentation performance (Jenkins et al. 1995). ORNL evaluated the surrogate recoveries using a statistical approach similar to that prescribed by SW 846 Method 8260 A Volatile Organic Compounds by Gas Chromatography/Mass Spectrometry (GC/MS) Capillary Column Technique (EPA 1992). Using this approach, ORNL reported that all surrogates had standard deviation values within the $95 \%$ confidence interval for variance, indicating that no bias was introduced in the measurement of analyte quantities (Jenkins 1995a).

\subsection{Positively Identified Organic Analytes}

Positive identification of organic analytes using the methods employed by PNL and ORNL involves matching the $\mathrm{GC}$ retention times and MS data from a sample with that obtained when known compounds were analyzed. The concentration of an analyte in the sample is said to be quantitatively measured if the response of the GC/MS has been established at several known concentrations of that analyte (i.e., the GC/MS has been calibrated for that analyte), and the MS response to the analyte in the sample is between the lowest and highest responses to the known concentrations (i.e., the analyte is within the calibration range).

ORNL and PNL were assigned different lists of organic compounds, or target analytes, to positively identify and measure quantitatively. The ORNL target analyte list was derived from a review of the tank $\mathrm{C}$ 103 headspace constituents by a panel of toxicology experts (Mahlum et al. 1994). The PNL target analyte list included 40 compounds in the Environmental Protection Agency (EPA) task order 14 (TO-14) method, which are primarily halocarbons and common industrial solvents (EPA 1988).

None of the 40 target analytes were detected by PNL above the 0.002 ppmv detection limit. Methane was measured by OGIST to be present at $[0.32 \mathrm{ppmv}]$, and is listed for consistency with reports similar to this in Table 4-1. 
Jenkins et al. (1995) positively identified 14 of 27 target analytes in 3 TST samples. The average concentration of propanone, the only quantitated analyte, is listed in Table 4-2. The other positively identified compounds were detected at levels outside the instrument calibration range in at least 1 TST sample. These are listed with their average concentrations in Tables 4-3 and 4-4. TST sample analyses occurred after the ORNL practical holding time for 1-butanol, which is segregated in Table 4-4, was exceeded. Tables $4-2,4-3$, and $4-4$ are mutually exclusive, so that no analyte appears in more than 1 of these tables.

The ORNL practical holding time is defined as the holding time for which there is a $15 \%$ risk that the concentration of an analyte in the sample will be below its initial concentration. As indicated in Table 4-4, of 1-butanol exceeded the practical holding time, and may have been affected by the 23 day period between sample collection and analysis (Jenkins 1995b). Jenkins et al (1995) describe the ORNL practical holding time study, and report practical holding time for butanal and 1-butanol to be 1 and 17 days, respectively. It is possible that butanal was not identified in the tank C-111 TST samples because the practical holding time for this compound was exceeded. It should be noted that the contractual holding time for the TST samples was 60 days.

Three target analytes were common to both the ORNL and PNL analyses: dichloromethane, benzene, and toluene Table 4-5). The average dichloromethane concentration reported by ORNL, $0.18 \mathrm{ppmv}$, is not supported by PNL analyses. Given that PNL found no dichloromethane, and that the observed dichloromethane concentration in TSTs varied widely (i.e., the 3 TST results were $0.0045,0.11$, and 0.43 ppmv; Jenkins et al. 1994), it is likely the ORNL result is the result of contamination, and is in error. ORNL detected trace amounts of benzene and toluene, but these were both below the limit of detection of PNL. (0.002 ppmv).

Except for dichloromethane, the 2 most abundant analytes are methane and ethanenitrile. At 0.32 ppmv, the methane concentration in tank C-111 is above ambient levels, which are typically about 0.2 ppmv. Elevated methane concentrations have been observed in other waste tank headspaces, and methane is probably formed during the chemical and radiolytic degradation of organic wastes. For methane, 0.32 ppmv corresponds to roughly $0.0006 \%$ of its LFL. Similarly, ethanenitrile, at measured concentration of 0.0093 ppmv presents virtually no flammable risk.

\subsection{Tentatively Identified Organic Analytes}

In addition to the target analytes, the ORNL and PNL analytical procedures allow the tentative identification of other organic compounds. Tentative identification of analytes was performed by comparing the MS molecular fragmentation patterns with a library of known MS fragmentation patterns. This method allows an organic analyte to be identified (with reasonable certainty) as an alkane, a ketone, an aldehyde, etc., and may also determine its molecular weight. The method usually does not, however, allow the unambiguous identification of structural isomers, and this ambiguity increases with analyte molecular weight. Using this method, many analytes can be tentatively identified with reasonable confidence without having to inject standards of each into the GC/MS to determine their GC retention times or specific MS patterns.

By the nature of the sampling devices, virtually all organic vapors present in the tank headspace are collected by both TST and SUMMA ${ }^{\mathrm{TM}}$ samples. Analyses of the samples are designed to recover, separate, and identify the organic vapors in the samples. TSTs are not good for collecting highiy volatile compounds (i.e., molecules more volatile than propane), but are quite good for most others. In contrast, the recovery of very low volatility compounds (e.g., molecules with more than about 15 carbon atoms) and 
some polar compounds with moderate volatility (e.g., butanal) from SUMMA ${ }^{\mathrm{TM}}$ samples has been problematic.

The PNL list of tentatively identified compounds, with estimated concentrations, is given in Table 4-6, and the ORNL list of tentatively identified compounds, and their estimated concentrations, is given in Table 47. Because the list of tentatively identified organic compounds in TST samples is long and finding any given compound may be difficult, the list has been sorted alphanumerically by compound name in Table 48. Table 4-9 gives the same list, sorted in order of decreasing estimated concentration. Numbers in the first columns of Tables 4-8 and 4-9 (Cmpd \#) identify the location of the compound in Table 4-7.

Estimated concentrations given in Tables 4-6 through $4-9$ are in $\mathrm{mg} / \mathrm{m}^{3}$, based on dry air at $0^{\circ} \mathrm{C}$ and 1.01 bar.

The PNL and ORNL methods used to tentatively identify and estimate concentrations are described by Jenkins et al. (1994) and Lucke et al. (1995), respectively, and should be reviewed before this data are used for decision making. Results in Tables 4-6 through 4-9 are presented in terms of observed peaks, and are not adjusted for the occurrence of split chromatographic peaks (e.g., Cmpd \# 22 and 28 in Table 4-7). In these instances, the estimated concentration of a compound appearing as a doublet or triplet is simply the sum of the individual peak estimates.

Concentrations given in Tables 4-6 and 4-7 should be considered rough estimates. The proper quantitation of all observed analytes is outside the scope and budget of these analyses, and the estimation of concentrations involves several important assumptions. The validity of each assumption depends on the analyte, and such factors as the specific configuration of the analytical instrumentation.

\subsection{Total Nonmethane Organic Carbon}

OGIST measured the TNMOC concentration in 3 SUMMATM canister samples using the EPA TO-12 method (Rasmussen 1994). The sample mean was $\left[0.18 \mathrm{mg} / \mathrm{m}^{3}\right]$, with a standard deviation of $[0.02$ $\mathrm{mg} / \mathrm{m}^{3} \mathrm{]}$. This value is very low compared to other waste tanks sampled to date. For comparison, the TNMOC concentration in clean ambient air may range from 0.03 to $0.10 \mathrm{mg} / \mathrm{m}^{3}$, and in polluted city air it may be 0.3 to $0.4 \mathrm{mg} / \mathrm{m}^{3}$.

\subsection{Discussion of Organic Analytes}

Some of the compounds listed in Tables 4-1 through 4-9 were introduced to the tank with process waste streams, and are detected in the headspace because the original inventory has not been completely evaporated or degraded. Examples of these are the semivolatile normal paraffinic hydrocarbons (NPHs), (e.g., n-dodecane and n-tridecane) that were used as a diluent for tributyl phosphate in several Hanford processes.

Most of the compounds in Tables 4-1 through 4-9 are believed to be chemical reaction and radiolytic reaction products of the semivolatile or nonvolatile organic waste stored in the tank. For example, 1butanol is known to be formed by the hydrolysis of tributyl phosphate, and it is thought that the alcohols, aldehydes, ketones, nitriles, alkenes, and short chain alkanes are all degradation products of NPHs.

Examination of the compounds listed in Tables 4-1 through 4-9 suggests many of the volatile species (presumed to be degradation products of the NPHs) have functional groups on the molecule's first or second carbon atom. Most alcohols are 1-alkanols, and ketones generally have the double bonded 
oxygen atom on the second carbon atom. Also, all the normal aldehydes from butanal through dodecanal were detected.

Though their concentrations are not significant, many alcohols and acids were tentatively identified by ORNL. These have generally not been observed to be as numerous in other NPH-rich tank headspaces, which tend to be dominated by aldehydes, ketones, alkanes, and alkenes.

The organic vapors in tank $\mathrm{C}-111$ are at very low concentrations compared to other passively ventilated tanks that have been sampled. Trace levels of the NPHs and their degradation products were found, but none were at levels of concern. 


\section{WHC-SD-WM-ER-425 REV. 2}

\subsection{SUMMARY}

The tank C-111 headspace was sampled in August 1993 and again in June 1994 for gases and vapors to address flammability and industrial hygiene concerns. Collection and analysis of samples has been reported. It was determined that no headspace constituents exceeded the flammability or industrial hygiene notification limits specified in the current Vapor Sampling and Analysis Plan (Homi 1995). 


\section{WHC-SD-WM-ER-425 REV. 2}

\subsection{REFERENCES}

29 CFR 1910.120, 1993, "Hazardous Waste Operations and Emergency Response", Code of Federal Regulations.

Burnum, S. T., 1995, Qualification of Reported WHC Vapor Program Data, (letter 95-CHD-065 to president, Westinghouse Hanford Company, August 18), Department of Energy, Richland Operations Office, Richland, Washington.

Cashdollar, K. L., M. Hertzberg, I. A. Zlochower, C. E. Lucci, G. M. Green, and R. A. Thomas, 1992, Laboratory Flammability Studies of Mixtures of Hydrogen, Nitrous Oxide, and Air, WHC-SD-WMES-219 Rev. 0, Westinghouse Hanford Company, Richland, Washington.

Dougherty, L. F., 1995, Single Shell Tank Interim Operational Safety Requirements, WHC-SD-WM-OSR005 Rev. 0, Westinghouse Hanford Company, Richland, Washing

EPA 1988, Compendium of Methods for the Determination of Toxic Organic Compounds in Ambient Air, PB90-127374, U.S. Environmental Protection Agency, Washington, D.C.

EPA 1992, Test Methods for Evaluating Solid Waste, SW-846 Rev. 1, U.S. Environmental Protection Agency, Washington, D.C.

Farley, W. G., 1991, Safety Assessment for Gas Sampling All Ferrocyanide Tanks, WHC-SD-WM-SAD009 Rev. 2, Westinghouse Hanford Company, Richland, Washington.

Hendrickson, R. W., 1995, Tank Vapor Characterization Oak Ridge National Laboratories Quality Assurance Assessment, TWRSQA-95-0012, Westinghouse Hanford Company, Richland, Washington.

Huckaby, J. L., 1994a, Vapor Sampling System (VSS) and In Situ Sampling (ISS) Method Comparison, WHC-SD-WM-RPT-101 Rev. 0, Westinghouse Hanford Company, Richland, Washington.

Huckaby, J. L., 1994b, Tank 241-C-111 Headspace Gas and Vapor Sample Results, August 1993 Samples, WHC-SD-WM-TP-254 Rev. 0, Westinghouse Hanford Company, Richland, Washington.

Huckaby, J. L., 1994c, Tank 241-C-103 Headspace Flammability, WHC-EP-0734 Rev. 1, Westinghouse Hanford Company, Richland, Washington.

Huckaby, J. L., H. Babad, and D. R. Bratzel, 1995, Headspace Gas and Vapor Characterization Summary for the 43 Vapor Program Suspect Tanks, WHC-SD-WM-ER-514 Rev. 0, Westinghouse Hanford Company, Richland, Washington.

Huckaby, J. L.and H. Babad, 1995, Waste Tank Headspace Gas and Vapor Characterization Reference Guide, WHC-SD-WM-ER-430 Rev. 0, Westinghouse Hanford Company, Richland, Washington.

Huckaby, J. L., 1995a, Tank 241-C-110 Vapor Sampling and Analysis Tank Characterization Report, WHC-SD-WM-ER-464, Rev.1, Westinghouse Hanford Company, Richland, Washington.

Huckaby, J. L., 1995b, Tank 241-C-112 Vapor Sampling and Analysis Tank Characterization Report, WHC-SD-WM-ER-426, Rev. 0, Westinghouse Hanford Company, Richland, Washington. 
WHC-SD-WM-ER-425 REV. 2

Huckaby, J. L., and M. S. Story, 1994, Vapor Characterization of Tank 241-C-103, WHC-EP-0780 Rev. 0, Westinghouse Hanford Company, Richland, Washington.

Jenkins, R. A., 1995a, Untitled, (Letter 090195A to D. Bratzel, September 1), Oak Ridge National Laboratory, Oak Ridge, Tennessee.

Jenkins, R. A., 1995b, Untitled, (Letter 091495A to D. Bratzel, September 14), Oak Ridge National Laboratory, Oak Ridge, Tennessee.

Jenkins, R. A, A. B. Dindal, C. E. Higgins, C. Y. Ma, and J. T. Skeen, 1994, Analysis of Tank 241-C-111 Headspace Components, Oak Ridge National Laboratory, Oak Ridge, Tennessee.

Jenkins, R. A. A. B. Dindal, C. Y. Ma, M. A. Palausky, J. T. Skeen, and C. K. Bayne, 1995, Analysis of Tank 241-TY-104 Headspace Components, ORNL-CASD-FR-241TY104.95 Rev. 1, Oak Ridge National Laboratory, Oak Ridge, Tennessee.

Keller, K. K., 1994, Quality Assurance Project Plan for Tank Vapor Characterization, WHC-SD-WMQAPP-013 Rev. 2, Westinghouse Hanford Company, Richland, Washington.

Ligotke, M. W., 1995, PNL Vapor Project Analytical Holding Times, (Letter to D. R. Bratzel, September 23 , 1995) Pacific Northwest Laboratory, Richland, Washington.

Ligotke, M. W., K. H. Pool, R. B. Lucke, B. D. MoVeety, T. W. Clauss, M. McCulloch, J. S. Young, J. S. Fruchter, and S. C. Goheen, 1995, Vapor Space Characterization of Waste Tank 241-C-111 in Situ): Results from Samples Collected on 6/20/94, PNL-10390 UC-606, Pacific Northwest Laboratory, Richland, Washington.

Lucke, R. B., T. W. Clauss, M. W. Ligotke, K. H. Pool, B. D. McVeety, J. S. Young, M. McCulloch, J. S. Fruchter, and S. C. Goheen, 1995, Vapor Space Characterization of Waste Tank 241-C-111: Results from Samples Collected with the Vapor Sampling System on 9/13/94, PNL-10390 UC606, Pacific Northwest Laboratory, Richland, Washington.

Mahlum, D. D., J. Y. Young, and R. E. Weller, 1994, Toxicologic Evaluation of Analytes from Tank 231-C103, PNL-10189, Pacific Northwest Laboratory, Richland, Washington.

Mahon, R., 1995, FY 1994 In-Situ Sampling System Summary Report, (Letter OM624-95-055 to Bratzel), Westinghouse Hanford Company, Richland, Washington.

Meacham, J. E., H. Babad, R. J. Cash, G. T. Dukelow, S. J. Eberlein, D. W. Hamilton, G. D. Johnson, J. W. Osborne, M. A. Payne, D. J. Sherwood, D. A. Turner, and J. L. Huckaby, 1995, Approach for Tank Safety Characterization of Hanford Site Waste, WHC-EP-0843 Rev. 0, UC-2070, Westinghouse Hanford Company, Richland, Washington.

Osborne, J. W., and J. L. Huckaby, 1994, Program Plan for the Resolution of Tank Vapor Issues, WHCEP-0562 Rev. 1, Westinghouse Hanford Company, Richland, Washington.

Osborne, J. W., J. L. Huckaby, T. P. Rudolph, E. R. Hewitt, D. D. Mahlum, J. Y. Young, C. M. Anderson, 1994, Data Quality Objectives for Generic In-Tank Health and Safety Issue Resolution, WHC-SDWM-DQO-002, Westinghouse Hanford Company, Richland, Washington. 


\section{WHC-SD-WM-ER-425 REV. 2}

Pingel, L. A., 1993, Results from the Vapor Sampling of Waste Tank C-111, (internal memorandum 12920-SAS93-062 to G. T. Dukelow, E. H. Neilsen, and W. H. Ulbricht, August 27) Westinghouse Hanford Company, Richland, Washington.

Pingel, L. A., 1995, Report from the In-Situ Vapor Sampling of Waste Tank C-111, (Internal memorandum 8E920-SAS95-191 to J. L. Huckaby), Westinghouse Hanford Company, Richland, Washington.

Rasmussen, R. A., 1994a, Air Samples Collected at Waste Tank 241-C-111 on September 13, 1994 by Westinghouse Hanford in 6-L SS SUMMA@ Canisters, Oregon Graduate Institute of Science and Technology, Beaverton, Oregon.

Rasmussen, R. A., and W. Einfeld, 1994, Hanford Tank 103-C Analyses and Method Validation Development Phase, SAND94-1807, Sandia National Laboratories, Albuquerque, New Mexico.

Saget, R.P., 1992, Hydrogen Cyanide Off-Gassing from Ferrocyanide Waste Tanks (Letter 9200668 to president Westinghouse Hanford Company, January 29) Department of Energy, Richland Operations Office, Richland, Washington.

WHC 1995a, Operating Specifications for Watchlist Tanks, OSD-T-151-00030, Rev. B-9, Westinghouse Hanford Company, Richland, Washington.

WHC 1995b, Vapor and Gas Sampling of Single-Shell Tank 241-C-111 Using the Vapor Sampling System, WHC-SD-WM-RPT-119, Westinghouse Hanford Company, Richland, Washington. 

WHC-SD-WM-ER-425 REV. 2

Table 2-1

Tank C-111 Gas and Vapor Sample Type and Number

\begin{tabular}{|c|c|c|c|c|}
\hline Laboratory & Sampling Device ${ }^{1}$ & $\begin{array}{c}\text { Nominal Sample } \\
\text { Volume (L) }\end{array}$ & Target Analytes & Number of Samples \\
\hline $\begin{array}{l}\text { Oak Ridge National } \\
\text { Laboratories }\end{array}$ & Triple Sorbent Trap & $\begin{array}{l}0.5 \\
2.0\end{array}$ & $\begin{array}{l}\text { Organic vapors } \\
\text { Organic vapors }\end{array}$ & $\begin{array}{l}8 \text { tank air samples } \\
8 \text { tank air samples } \\
+2 \text { trip blanks }\end{array}$ \\
\hline $\begin{array}{l}\text { Oregon Graduate Institute of } \\
\text { Science and Technology }\end{array}$ & SUMMA ${ }^{T M}$ canister & 6.0 & $\begin{array}{l}\text { Hydrogen, } \\
\text { Nitrous Oxide, Carbon } \\
\text { Dioxide, Carbon } \\
\text { Monoxide } \\
\end{array}$ & 3 tank air samples \\
\hline \multirow[t]{5}{*}{$\begin{array}{l}\text { Pacific Northwest } \\
\text { Laboratories }\end{array}$} & Acidified Carbon Sorbent Trap & 3.0 & Ammonia & $\begin{array}{l}6 \text { tank air samples } \\
+3 \text { trip blanks }\end{array}$ \\
\hline & Triethanolamine Sorbent Trap & 3.0 & Nitrogen Dioxide & $\begin{array}{l}6 \text { tank air samples } \\
+3 \text { trip blanks }\end{array}$ \\
\hline & $\begin{array}{l}\text { Oxidation bed + } \\
\text { Triethanolemine Sorbent Trap }\end{array}$ & 3.0 & Nitric Oxide & $\begin{array}{l}6 \text { tank air samples } \\
+3 \text { trip blanks }\end{array}$ \\
\hline & Silica Gel Sorbent Trap & 3.0 & Water vapor & $\begin{array}{l}6 \text { tank air samples } \\
+3 \text { trip blanks }\end{array}$ \\
\hline & SUMMA ${ }^{\text {TM }}$ canister & 6.0 & Organic vapors & $\begin{array}{l}3 \text { tank air samples } \\
+2 \text { ambient air samples }\end{array}$ \\
\hline WHC 222-S Laboratory & Silica Gel Sorbent Trap & 1.0 & $\begin{array}{l}\text { Tritium-Substituted Water } \\
\text { Vapor }\end{array}$ & 1 tank air sample \\
\hline
\end{tabular}

1 Sampling Temperature: $-50^{\circ} \mathrm{C}$ 


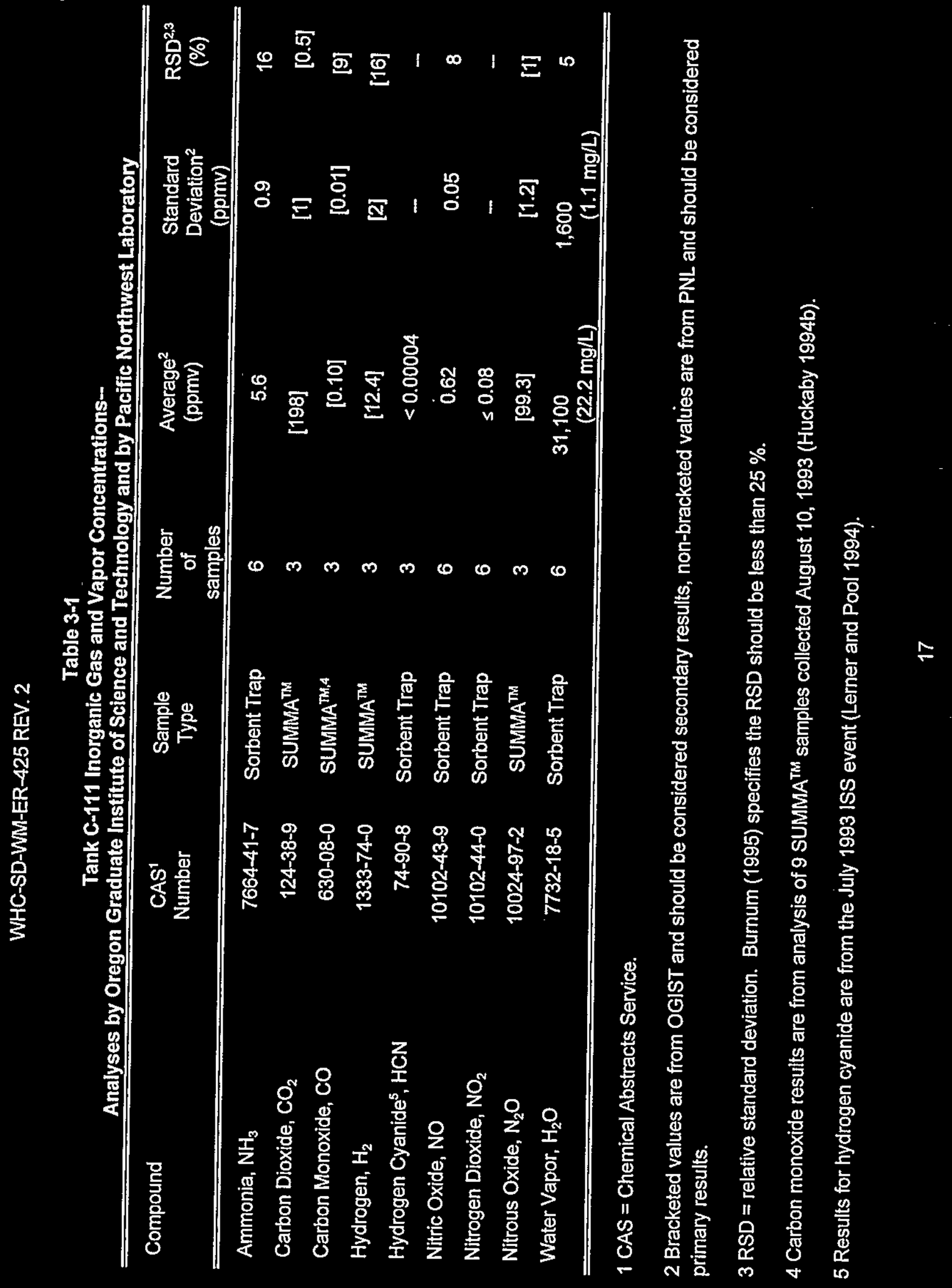


Table 3-2

Comparison of Tank C-110, C-111, and C-112 Headspace Constituents Inorganic Analyses by Oregon Graduate Institute of Science and Technology, and Organic Analyses by Oak ridge National Laboratory'

\begin{tabular}{|c|c|c|c|}
\hline Tank: & $\mathrm{C}-110^{2}$ & $\mathrm{C}-111^{3}$ & $\mathrm{C}-112^{4}$ \\
\hline Date sampled, (mo/day/yr) & $8 / 8 / 94$ & $9 / 13 / 94$ & $8 / 11 / 94$ \\
\hline Headspace temperature, $\left({ }^{\circ} \mathrm{C}\right)$ & 21.9 & 27 & 28 \\
\hline Sampling Temperature, $\left({ }^{\circ} \mathrm{C}\right)$ & 50 & 50 & 50 \\
\hline Ammonia, (ppmv) & 124 & 5.6 & 22.7 \\
\hline Hydrogen, (ppmv) & [12] & [12.4] & [204] \\
\hline Carbon dioxide, (ppmv) & [42] & [198] & [102] \\
\hline Carbon monoxide, (ppmv) & {$[0.7]$} & {$[0.10]$} & [0.92] \\
\hline Nitric oxide, (ppmv) & 0.08 & 0.62 & 0.62 \\
\hline Nitrogen dioxide, (ppmv) & $\leq 0.06$ & $\leq 0.08$ & $\leq 0.02$ \\
\hline Nitrous oxide, (ppmv) & {$[9.4]$} & [99.3] & [544] \\
\hline Water vapor, $\left(\mathrm{mg} / \mathrm{m}^{3}\right)$ & 12.4 & 22.2 & 22.3 \\
\hline Water vapor, (\% relative humidity) & 64 & 86 & 82 \\
\hline Ethanenitrile (acetonitrile), (ppmv) & $(0.17)$ & 0.0093 & $(3.0)$ \\
\hline Propanone (acetone), (ppmv) & $(0.21)$ & 0.0080 & $(0.078)$ \\
\hline 1-Butanol, (ppmv) & $(0.73)$ & $(0.0016)$ & 0.0044 \\
\hline n-Dodecane, (ppmv) & $(0.084)$ & $(0.00054)$ & $(0.00043)$ \\
\hline n-Tridecane, (ppmv) & $(0.15)$ & $(0.0012)$ & $(0.00060)$ \\
\hline $\begin{array}{l}\text { Total nonmethane organic compounds by EPA TO-12 } \\
\text { method, }\left(\mathrm{mg} / \mathrm{m}^{3}\right)\end{array}$ & [22.2] & {$[0.18]$} & [3.4] \\
\hline
\end{tabular}

1 Where PNL inorganic gas or vapor data were unavailable for tanks $\mathrm{C}-111$ and $\mathrm{C}-112$, OCIST results are given in brackets to indicate the data should be considered secondary results. Organic vapor results are from ORNL, with semiquantitative values in parentheses and quantitative values not in parentheses.

2 Data from Huckaby 1995a.

3 To be consistent with data from tanks $\mathrm{C}-110$ and $\mathrm{C}-112$, results for individual organic compounds given in this column are from 3, 2-L TST samples analyzed by ORNL. Inorganic data is based on analyses of 3 SUMMA ${ }^{\text {TM }}$ samples by OGIST.

4 Data are from Huckaby 1995b. 
Table 4-1

Tank C-111 Quantitatively Measured Organic Compounds in SUMMA ${ }^{\text {m }}$ Samples Analyses by Oregon Graduate Institute of Science and Technology

\begin{tabular}{ccccccc}
\hline \hline Cmpd\# & Compound & $\begin{array}{c}\text { CAS } \\
\text { Number }\end{array}$ & $\begin{array}{c}\text { Average } \\
(\mathrm{ppmV})\end{array}$ & $\begin{array}{c}\text { Standard } \\
\text { Deviation } \\
\text { (ppmv) }\end{array}$ & $\begin{array}{c}\mathrm{RSD}^{3} \\
(\%)\end{array}$ \\
\hline \hline 1 & Methane $^{4}$ & $74-82-8$ & {$[0.32]$} & {$[0.02]$} & {$[5]$} \\
\hline \hline
\end{tabular}

$1 \mathrm{CAS}=$ Chemical Abstract Service.

2 Average of 3 samples.

3 RSD = Relative Standard Deviation. Burnum (1995) specifies the RSD should be less than $25 \%$.

4 Methane analyses were performed by OGIST and should be considered a secondary result (Ramussen 1994). 


\section{WHC-SD-WM-ER-425 REV. 2}

Table 4-2

Tank C-111 Quantitatively Measured Organic Compounds in TST Samples -Analyses by Oak Ridge National Laboratory ${ }^{4}$

\begin{tabular}{|c|c|c|c|c|c|}
\hline$\underset{\#}{\text { Cmpd }}$ & Compound & $\begin{array}{c}\mathrm{CAS}^{2} \\
\text { Number }\end{array}$ & $\begin{array}{c}\text { Average }^{3} \\
\text { (ppmv) }\end{array}$ & $\begin{array}{c}\text { Standard } \\
\text { Deviation } \\
\text { (ppmv) }\end{array}$ & $\begin{array}{l}\text { RSD }^{4} \\
(\%)\end{array}$ \\
\hline 1 & Propanone (acetone) & $67-64-1$ & 0.0080 & 0.0019 & 24 \\
\hline
\end{tabular}

1 Results in this table are quantitative (as defined in Section 4.1).

$2 \mathrm{CAS}=$ Chemical Abstract Service.

3 Average of 3, 2-L samples.

$4 \mathrm{RSD}=$ Relative Standard Deviation. Burnum (1995) specifies the RSD should be less than $25 \%$. 
Table 4-3

Tank C-111 Positively Identified Organic Compounds in TST Samples -Analyses by Oak Ridge National Laboratory ${ }^{1}$

\begin{tabular}{clcccc}
\hline \hline $\begin{array}{c}\text { Cmpd } \\
\#\end{array}$ & Compound & $\begin{array}{c}\text { CAS }^{2} \\
\text { Number }\end{array}$ & $\begin{array}{c}\text { Average } \\
\text { (ppmv) }\end{array}$ & $\begin{array}{c}\text { Standard } \\
\text { Deviation } \\
\text { (ppmv) }\end{array}$ & $\begin{array}{c}\text { RSD }^{4} \\
(\%)\end{array}$ \\
\hline \hline 1 & $\begin{array}{c}\text { Ethanenitrile } \\
\text { (acetonitrile) }\end{array}$ & $75-05-8$ & 0.0093 & 0.0019 & 20 \\
2 & Dichloromethane & $75-09-2$ & 0.18 & 0.21 & 116 \\
3 & n-Hexane & $110-54-3$ & 0.00044 & 0.00022 & 50 \\
4 & Benzene & $71-43-2$ & 0.00056 & 0.00010 & 18 \\
5 & Toluene & $108-88-3$ & 0.00036 & 0.00003 & 8 \\
6 & 2-Hexanone & $591-78-6$ & 0.00032 & 0.00007 & 21 \\
7 & n-Octane & $111-65-9$ & 0.000034 & 0.000056 & 163 \\
8 & 2-Heptanone & $110-43-0$ & 0.00032 & 0.00005 & 15 \\
9 & n-Nonane & $111-84-2$ & 0.000084 & 0.000071 & 85 \\
10 & 2-Octanone & $111-13-7$ & 0.00020 & 0.00003 & 14 \\
11 & n-Dodecane & $112-70-3$ & 0.00054 & 0.00005 & 9 \\
12 & n-Tridecane & $629-50-5$ & 0.0012 & 0.0001 & 7 \\
\hline \hline
\end{tabular}

1 Results in this table are not quantitative (as defined in Section 4.1) because measured values in at least 1 of the samples are outside instrument calibration limits.

$2 \mathrm{CAS}=$ Chemical Abstract Service.

3 Average of 3, 2-L samples, values listed are estimates.

4 RSD = Relative Standard Deviation. Burnum (1995) specifies the RSD should be less than $25 \%$. 
Table 4-4

Tank C-111 Positively Identified Organic Compound in TST Samples for which Practical Holding Times were Exceeded Analyses by Oak Ridge National Laboratory ${ }^{1}$

\begin{tabular}{cccccc}
$\begin{array}{c}\text { Cmpd } \\
\#\end{array}$ & Compound & $\begin{array}{c}\text { CAS }^{2} \\
\text { Number }\end{array}$ & $\begin{array}{c}\text { Average } \\
\text { (ppmv) }\end{array}$ & $\begin{array}{c}\text { Standard } \\
\text { Deviation } \\
\text { (ppmv) }\end{array}$ & $\begin{array}{c}\mathrm{RSD}^{4} \\
(\%)\end{array}$ \\
\hline \hline 1 & 1-Butanol & & 0.0005 & 29 \\
\hline \hline
\end{tabular}

1 Practical holding times are defined and discussed in Section 4.1.

$2 \mathrm{CAS}=$ Chemical Abstract Service.

3 Average of 3, 2-L samples, values listed are estimates.

4 RSD = Relative Standard Deviation. Burnum (1995) specifies the RSD should be less than $25 \%$.

5 The concentration of this analyte was not quantitatively measured (as defined in Section 4.1), because the measured concentration was outside of the instrumental callibration limits. 


\section{Table $4-5$}

Tank C-111 Comparison of Organic Compounds in TST and SUMMA ${ }^{\text {TM }}$ Samples Analyses by Pacific Northwest Laboratory and Oak Ridge National Laboratory

\begin{tabular}{clcccc}
$\begin{array}{c}\text { Cmpd } \\
\#\end{array}$ & Compound & $\begin{array}{c}\text { CAS }^{1} \\
\text { Number }\end{array}$ & $\begin{array}{c}\text { TST } \\
\text { Average } \\
\text { (ppmv) }\end{array}$ & $\begin{array}{c}\text { SUMMA }^{\text {TM }} \\
\text { Average }^{3} \\
\text { (ppmv) }\end{array}$ & $\begin{array}{c}\text { PRD }^{4} \\
(\%)\end{array}$ \\
\hline 1 & Dichloromethane & $75-09-2$ & 0.18 & $<0.002$ & $>196$ \\
2 & Benzene & $71-43-2$ & 0.00056 & $<0.002$ & - \\
3 & Toluene & $108-88-3$ & 0.00036 & $<0.002$ & - \\
\hline \hline
\end{tabular}

$1 \mathrm{CAS}=$ Chemical Abstract Service .

2 Average of 3, 2-L samples.

3 Average of 3 samples analyses.

$4 \mathrm{PRD}=$ percent relative difference. Keller (1994) requires the PRD to be less than $20 \%$. 
WHC-SD-WM-ER-425 REV. 2

Table 4-6

Tank C-111 Tentatively Identified Organic Compounds in SUMMA ${ }^{\text {TM }}$ Samples -Analyses by Pacific Northwest Laboratory

\begin{tabular}{|c|c|c|c|c|}
\hline $\begin{array}{c}\text { Cmpd } \\
\#\end{array}$ & Compounds & $\begin{array}{c}\text { CAS }^{1} \\
\text { Number }\end{array}$ & $\begin{array}{l}\text { Average } \\
\left(\mathrm{mg} / \mathrm{m}^{3}\right)\end{array}$ & $\begin{array}{l}\text { Standard } \\
\text { Deviation } \\
\left(\mathrm{mg} / \mathrm{m}^{3}\right)\end{array}$ \\
\hline 1 & Ethanal (acetaldehyde) & $75-07-0$ & 0.093 & 0.093 \\
\hline 2 & Propanone (acetone) & $110-62-3$ & 0.075 & 0.075 \\
\hline 3 & Butanal2 $^{2}$ & $123-72-8$ & 0.040 & - \\
\hline 4 & 2-Butanone ${ }^{2}$ & $78-93-3$ & 0.020 & - \\
\hline 5 & Pentanal $\left.\right|^{2}$ & $110-62-3$ & 0.039 & - \\
\hline 6 & Hexanal $^{2}$ & $66-25-1$ & 0.049 & - \\
\hline 7 & Heptanal & $111-71-7$ & 0.055 & 0.005 \\
\hline 8 & C6-alkene ${ }^{2}$ & & 0.033 & - \\
\hline 9 & Octanal & $124-13-0$ & 0.063 & 0.008 \\
\hline 10 & Nonanal & $124-19-6$ & 0.066 & 0.014 \\
\hline 11 & C7-alkene ${ }^{2}$ & & 0.019 & - \\
\hline 12 & Decanal $^{2}$ & $112-31-2$ & 0.023 & - \\
\hline \multicolumn{3}{|c|}{ Sum of tentatively identified compounds: } & 0.58 & \\
\hline
\end{tabular}

$1 \mathrm{CAS}=$ Chemical Abstract Service.

2 Detected in only 1 sample. 
Table 4-7

Tank C-111 Tentatively Identified Organic Compounds in TST Samples in Order of Chromatographic Elution Analyses by Oak Ridge National Laboratory

\begin{tabular}{|c|c|c|c|c|}
\hline Cmpd & Compound & $\begin{array}{l}\text { CAS }^{1} \\
\text { Number }\end{array}$ & $\begin{array}{l}\text { Average } 2 \\
\left(\mathrm{mg} / \mathrm{m}^{3}\right)\end{array}$ & $\begin{array}{c}\text { Standard } \\
\text { Deviation } \\
\left(\mathrm{mg} / \mathrm{m}^{3}\right)\end{array}$ \\
\hline 1 & Methane, trichlorofluoro- & $75-69-4$ & 0.035 & 0.0613 \\
\hline 2 & Acetic acid & $64-19-7$ & 0.038 & 0.0081 \\
\hline 3 & Hexanal & $66-25-1$ & 0.003 & 0.0054 \\
\hline 4 & Cyclotrisiloxane, hexamethyl- & $541-05-9$ & 0.003 & 0.0044 \\
\hline 5 & Heptanal & $111-71-7$ & 0.006 & 0.0022 \\
\hline 6 & Phenol & $108-95-2$ & 0.007 & 0.0011 \\
\hline 7 & Cyclotetrasiloxane, octamethyl- & $556-67-2$ & 0.008 & 0.0052 \\
\hline 8 & Octanal & $124-13-0$ & 0.010 & 0.0026 \\
\hline 9 & 1-Hexanol, 2-ethyl- & $104-76-7$ & 0.009 & 0.0009 \\
\hline 10 & 1-Octanol & $111-87-5$ & 0.001 & 0.0023 \\
\hline 11 & Ethanone, 1-phenyl- & $98-86-2$ & 0.001 & 0.0023 \\
\hline 12 & Phenol, 2-methyl- & $95-48-7$ & 0.001 & 0.0026 \\
\hline 13 & Nonanal & $124-19-6$ & 0.020 & 0.0052 \\
\hline 14 & $\begin{array}{l}\text { Benzeneacetic acid, a, } \\
\text { 4-bis!(trimethylsilyl)oxyl-, methyl ester }\end{array}$ & $55334-40-2$ & 0.003 & 0.0027 \\
\hline 15 & 2-Nonenal, (E) & $18829-56-6$ & 0.002 & 0.0038 \\
\hline 16 & 1-Nonanol & $143-08-8$ & 0.004 & 0.0006 \\
\hline 17 & Decanal & $112-31-2$ & 0.011 & 0.0020 \\
\hline 18 & Benzothiazole & $95-16-9$ & 0.003 & 0.0005 \\
\hline 19 & Alkanoic acid and others & & 0.002 & 0.0028 \\
\hline 20 & 2(3H)-Furanone, dihydro-5-propyl- & $105-21-5$ & 0.001 & 0.0012 \\
\hline 21 & 3-octene & $592-98-3$ & 0.001 & 0.0013 \\
\hline 22 & Dodecanal & $112-54-9$ & 0.003 & 0.0024 \\
\hline 23 & 5-Nonanone & $502-56-7$ & 0.009 & 0.0009 \\
\hline 24 & $\begin{array}{l}\text { 2,5-Pyrrolidinedione, 3-ethyl-3-hydroxy- \& } \\
\text { others }\end{array}$ & & 0.007 & 0.0008 \\
\hline
\end{tabular}




\begin{tabular}{|c|c|c|c|c|}
\hline$\underset{\#}{C \text { Cmpd }}$ & Compound & $\begin{array}{c}\text { CAS }^{1} \\
\text { Number }\end{array}$ & $\begin{array}{l}\text { Average }^{2} \\
\left(\mathrm{mg} / \mathrm{m}^{3}\right)\end{array}$ & $\begin{array}{c}\text { Standard } \\
\text { Deviation } \\
\left(\mathrm{mg} / \mathrm{m}^{3}\right)\end{array}$ \\
\hline 25 & 2-Nonanone & $821-55-6$ & 0.002 & 0.0032 \\
\hline 26 & 2-Octanol & $123-96-6$ & 0.001 & 0.0012 \\
\hline 27 & Phthalate & & 0.001 & 0.0014 \\
\hline 28 & Dodecanal & $112-54-9$ & 0.001 & 0.0011 \\
\hline 29 & 5,9-Undecadien-2-one, 6,10-dimethyl-(Z) & $3879-26-3$ & 0.001 & 0.0023 \\
\hline 30 & Undecanal & $112-44-7$ & 0.002 & 0.0021 \\
\hline 31 & Benzenamine, n-phenyl- \& others & & 0.001 & 0.0026 \\
\hline 32 & Decane, 1,1'-oxybis- & $2456-28-2$ & 0.008 & 0.0025 \\
\hline 33 & $\begin{array}{l}\text { 9H-fluorene, 3-methyl-and } \\
\text { di-t-butyl-ethylphenol }\end{array}$ & & 0.004 & 0.0019 \\
\hline 34 & $\begin{array}{l}\text { 2,5-cyclohexadiene-1,4-dione, } \\
\text { 2,6-bis(1,1-dimethylethyl)- }\end{array}$ & $719-22-2$ & 0.003 & 0.0017 \\
\hline 35 & Alkanol & & 0.001 & 0.0018 \\
\hline 36 & 2-Decanone & $693-54-9$ & 0.001 & 0.0013 \\
\hline 37 & 2-Dodecanone & $6175-49-1$ & 0.002 & 0.0019 \\
\hline 38 & Decanoic acid & $334-48-5$ & 0.001 & 0.0016 \\
\hline 39 & Hexadecanoic acid & $57-10-3$ & 0.001 & 0.0020 \\
\hline 40 & 1,2-Benzenedicarboxylic acid, diethyl ester & $84-66-2$ & 0.009 & 0.0014 \\
\hline 41 & Benzenamine, n-phenyl- & $122-39-4$ & 0.008 & 0.0017 \\
\hline 42 & 1-Hexanol, 2-ethyl- & $104-76-7$ & 0.001 & 0.0011 \\
\hline 43 & Tetradecanoic acid & $544-63-8$ & 0.013 & 0.0046 \\
\hline 44 & Alkane & & 0.004 & 0.0036 \\
\hline 45 & Decane, 4-cyclohexyl-, 4-cyclohexyl- & $13151-75-2$ & 0.001 & 0.0012 \\
\hline 46 & Alkane & & 0.002 & 0.0036 \\
\hline 47 & 9-Octadecenoic acid, (Z)- & $112-80-1$ & 0.001 & 0.0015 \\
\hline 48 & Pentadecanoic acid & $1002-84-2$ & 0.006 & 0.0032 \\
\hline 49 & 1-Octadecene & $112-88-9$ & 0.001 & 0.0011 \\
\hline 50 & 9-Octadecen-1-ol, (Z) & $143-28-2$ & 0.002 & 0.0031 \\
\hline 51 & 9-Hexadecenoic acid & $2091-29-4$ & 0.010 & 0.0095 \\
\hline
\end{tabular}


WHC-SD-WM-ER-425 REV. 2

\begin{tabular}{llrrr}
$\begin{array}{c}\text { Cmpd } \\
\#\end{array}$ & Compound & $\begin{array}{c}\mathrm{CAS}^{1} \\
\text { Number }\end{array}$ & $\begin{array}{c}\text { Average } \\
\left(\mathrm{mg} / \mathrm{m}^{3}\right)\end{array}$ & $\begin{array}{c}\text { Standard } \\
\text { Deviation } \\
\left(\mathrm{mg} / \mathrm{m}^{3}\right)\end{array}$ \\
\hline 52 & Hexadecanoic acid & $57-10-3$ & 0.041 & 0.0159 \\
53 & Eicosane & $112-95-8$ & 0.005 & 0.0049 \\
54 & $1-$ Hexadecanol & $36653-82-4$ & 0.001 & 0.0025 \\
55 & 16-Methylheptadecanol-1 & & 0.001 & 0.0025 \\
\hline Sum of tentatively identified compounds: & & 0.33 & \\
\hline \hline
\end{tabular}

1 Chemical Abstract Service.

2 Average of 3, 2-L samples, values listed are estimates. 
Tank C-111 Tentatively Identified Organic Compounds in TST Samples Sorted Alphanumerically -Analyses by Oak Ridge National Laboratory

\begin{tabular}{|c|c|c|c|c|}
\hline$\underset{\#}{\text { Cmpd }}$ & Compound & $\begin{array}{l}\text { CAS }^{1} \\
\text { Number }\end{array}$ & $\begin{array}{l}\text { Average }^{2} \\
\left(\mathrm{mg} / \mathrm{m}^{3}\right)\end{array}$ & $\begin{array}{c}\text { Standard } \\
\text { Deviation } \\
\left(\mathrm{mg} / \mathrm{m}^{3}\right)\end{array}$ \\
\hline 49 & 1-Octadecene & $112-88-9$ & 0.001 & 0.0011 \\
\hline 9 & 1-Hexanol, 2-ethyl- & $104-76-7$ & 0.009 & 0.0009 \\
\hline 54 & 1-Hexadecanol & $36653-82-4$ & 0.001 & 0.0025 \\
\hline 42 & 1-Hexanol, 2-ethyl- & $104-76-7$ & 0.001 & 0.0011 \\
\hline 16 & 1 -Nonanol & $143-08-8$ & 0.004 & 0.0006 \\
\hline 10 & 1-Octanol & $111-87-5$ & 0.001 & 0.0023 \\
\hline 15 & 2-Nonenal, (E) & $18829-56-6$ & 0.002 & 0.0038 \\
\hline 26 & 2-Octanol & $123-96-6$ & 0.001 & 0.0012 \\
\hline 37 & 2-Dodecanone & $6175-49-1$ & 0.002 & 0.0019 \\
\hline 36 & 2-Decanone & $693-54-9$ & 0.001 & 0.0013 \\
\hline 25 & 2-Nonanone & $821-55-6$ & 0.002 & 0.0032 \\
\hline 23 & 5-Nonanone & $502-56-7$ & 0.009 & 0.0009 \\
\hline 50 & 9-Octadecen-1-ol, (Z) & $143-28-2$ & 0.002 & 0.0031 \\
\hline 47 & 9-Octadecenoic acid, (Z)- & $112-80-1$ & 0.001 & 0.0015 \\
\hline 51 & 9-Hexadecenoic acid & $2091-29-4$ & 0.010 & 0.0095 \\
\hline 33 & $\begin{array}{l}\text { 9H-fluorene, 3-methyl-and } \\
\text { di-t-butyl-ethylphenol }\end{array}$ & & 0.004 & 0.0019 \\
\hline 40 & 1,2-Benzenedicarboxylic acid, diethyl ester & $84-66-2$ & 0.009 & 0.0014 \\
\hline 55 & 16-Methylheptadecanol-1 & & 0.001 & 0.0025 \\
\hline 20 & 2(3H)-Furanone, dihydro-5-propyl- & $105-21-5$ & 0.001 & 0.0012 \\
\hline 34 & $\begin{array}{l}\text { 2,5-cyclohexadiene-1,4-dione, } \\
\text { 2,6-bis(1,1-dimethylethyl)- }\end{array}$ & $719-22-2$ & 0.003 & 0.0017 \\
\hline 24 & $\begin{array}{l}\text { 2,5-Pyrrolidinedione, 3-ethyl-3-hydroxy- \& } \\
\text { others }\end{array}$ & & 0.007 & 0.0008 \\
\hline 29 & 5,9-Undecadien-2-one, 6,10-dimethyl-(Z) & $3879-26-3$ & 0.001 & 0.0023 \\
\hline 2 & Acetic acid & $64-19-7$ & 0.038 & 0.0081 \\
\hline 44 & Alkane & & 0.004 & 0.0036 \\
\hline
\end{tabular}




\begin{tabular}{|c|c|c|c|c|}
\hline$\underset{\#}{\text { Cmpd }}$ & Compound & $\begin{array}{l}\text { CAS }^{1} \\
\text { Number }\end{array}$ & $\begin{array}{l}\text { Average }^{2} \\
\left(\mathrm{mg} / \mathrm{m}^{3}\right)\end{array}$ & $\begin{array}{c}\text { Standard } \\
\text { Deviation } \\
\left(\mathrm{mg} / \mathrm{m}^{3}\right) \\
\end{array}$ \\
\hline 46 & Alkane & & 0.002 & 0.0036 \\
\hline 19 & Alkanoic acid and others & & 0.002 & 0.0028 \\
\hline 35 & Alkanol & & 0.001 & 0.0018 \\
\hline 31 & Benzenamine, $n$-phenyl- \& others & & 0.001 & 0.0026 \\
\hline 41 & Benzenamine, n-phenyl- & $122-39-4$ & 0.008 & 0.0017 \\
\hline 14 & $\begin{array}{l}\text { Benzeneacetic acid, a, } \\
\text { 4-bis[(trimethylsilyl)oxy]-, methyl ester }\end{array}$ & $55334-40-2$ & 0.003 & 0.0027 \\
\hline 18 & Benzothiazole & $95-16-9$ & 0.003 & 0.0005 \\
\hline 7 & Cyclotetrasiloxane, octamethyl- & $556-67-2$ & 0.008 & 0.0052 \\
\hline 4 & Cyclotrisiloxane, hexamethyl- & $541-05-9$ & 0.003 & 0.0044 \\
\hline 17 & Decanal & $112-31-2$ & 0.011 & 0.0020 \\
\hline 45 & Decane, 4-cyclohexyl-, 4-cyclohexyl- & $13151-75-2$ & 0.001 & 0.0012 \\
\hline 32 & Decane, $1,1^{\prime}$-oxybis- & $2456-28-2$ & 0.008 & 0.0025 \\
\hline 38 & Decanoic acid & $334-48-5$ & 0.001 & 0.0016 \\
\hline 28 & Dodecanal & $112-54-9$ & 0.001 & 0.0011 \\
\hline 22 & Dodecanal & $112-54-9$ & 0.003 & 0.0024 \\
\hline 53 & Eicosane & $112-95-8$ & 0.005 & 0.0049 \\
\hline 11 & Ethanone, 1-phenyl- & $98-86-2$ & 0.001 & 0.0023 \\
\hline 5 & Heptanal & $111-71-7$ & 0.006 & 0.0022 \\
\hline 52 & Hexadecanoic acid & $57-10-3$ & 0.041 & 0.0159 \\
\hline 39 & Hexadecanoic acid & $57-10-3$ & 0.001 & 0.0020 \\
\hline 3 & Hexanal & $66-25-1$ & 0.003 & 0.0054 \\
\hline 1 & Methane, trichlorofluoro- & $75-69-4$ & 0.035 & 0.0613 \\
\hline 21 & 3-octene & $592-98-3$ & 0.001 & 0.0013 \\
\hline 13 & Nonanal & $124-19-6$ & 0.020 & 0.0052 \\
\hline 8 & Octanal & $124-13-0$ & 0.010 & 0.0026 \\
\hline 48 & Pentadecanoic acid & $1002-84-2$ & 0.006 & 0.0032 \\
\hline 6 & Phenol & $108-95-2$ & 0.007 & 0.0011 \\
\hline 12 & Phenol, 2-methyl- & $95-48-7$ & 0.001 & 0.0026 \\
\hline
\end{tabular}


WHC-SD-WM-ER-425 REV. 2

\begin{tabular}{clccc}
\hline $\begin{array}{c}\text { Cmpd } \\
\#\end{array}$ & Compound & $\begin{array}{c}\mathrm{CAS}^{1} \\
\text { Number }\end{array}$ & $\begin{array}{c}\text { Average } \\
\left(\mathrm{mg} / \mathrm{m}^{3}\right)\end{array}$ & $\begin{array}{c}\text { Standard } \\
\text { Deviation } \\
\left(\mathrm{mg} / \mathrm{m}^{3}\right)\end{array}$ \\
\hline 27 & Phthalate & & 0.001 & 0.0014 \\
43 & Tetradecanoic acid & $544-63-8$ & 0.013 & 0.0046 \\
30 & Undecanal & $112-44-7$. & 0.002 & 0.0021 \\
\hline \hline Sum of tentatively identified compounds: & & 0.33 & \\
\hline \hline
\end{tabular}

1 Chemical Abstract Service.

2 Average of 3, 2-L samples, values listed are estimates. 
Table $4-9$

Tank C-111 Tentatively Identified Organic Compounds in TST Samples Sorted by Estimated Concentration Analyses by Oak Ridge National Laboratory

\begin{tabular}{|c|c|c|c|c|}
\hline$\underset{\#}{\text { Cmpd }}$ & Compound & $\begin{array}{l}\text { CAS }^{1} \\
\text { Number }\end{array}$ & $\begin{array}{l}\text { Average }{ }^{2} \\
\left(\mathrm{mg} / \mathrm{m}^{3}\right)\end{array}$ & $\begin{array}{c}\text { Standard } \\
\text { Deviation } \\
\left(\mathrm{mg} / \mathrm{m}^{3}\right) \\
\end{array}$ \\
\hline 52 & Hexadecanoic acid & $57-10-3$ & 0.041 & 0.0159 \\
\hline 2 & Acetic acid & $64-19-7$ & 0.038 & 0.0081 \\
\hline 1 & Methane, trichlorofluoro- & $75-69-4$ & 0.035 & 0.0613 \\
\hline 13 & Nonanal & $124-19-6$ & 0.020 & 0.0052 \\
\hline 43 & Tetradecanoic acid & $544-63-8$ & 0.013 & 0.0046 \\
\hline 17 & Decanal & $112-31-2$ & 0.011 & 0.0020 \\
\hline 51 & 9-Hexadecenoic acid & $2091-29-4$ & 0.010 & 0.0095 \\
\hline 8 & Octanal & $124-13-0$ & 0.010 & 0.0026 \\
\hline 9 & 1-Hexanol, 2-ethyl- & $104-76-7$ & 0.009 & 0.0009 \\
\hline 40 & 1,2-Benzenedicarboxylic acid, diethyl ester & $84-66-2$ & 0.009 & 0.0014 \\
\hline 23 & 5-Nónanone & $502-56-7$ & 0.009 & 0.0009 \\
\hline 7 & Cyclotetrasiloxane, octamethyl- & $556-67-2$ & 0.008 & 0.0052 \\
\hline 32 & Decane, $1,1^{\prime}$-oxybis- & $2456-28-2$ & 0.008 & 0.0025 \\
\hline 41 & Benzenamine, n-phenyl- & $122-39-4$ & 0.008 & 0.0017 \\
\hline 6 & Phenol & $108-95-2$ & 0.007 & 0.0011 \\
\hline 24 & $\begin{array}{l}\text { 2,5-Pyrrolidinedione, 3-ethyl-3-hydroxy- \& } \\
\text { others }\end{array}$ & & 0.007 & 0.0008 \\
\hline 48 & Pentadecanoic acid & $1002-84-2$ & 0.006 & 0.0032 \\
\hline 5 & Heptanal & $111-71-7$ & 0.006 & 0.0022 \\
\hline 53 & Eicosane & $112-95-8$ & 0.005 & 0.0049 \\
\hline 16 & 1-Nonanol & $143-08-8$ & 0.004 & 0.0006 \\
\hline 44 & Alkane & & 0.004 & 0.0036 \\
\hline 33 & $\begin{array}{l}\text { 9H-fluorene, 3-methyl-and } \\
\text { di-t-butyl-ethylphenol }\end{array}$ & & 0.004 & 0.0019 \\
\hline 22 & Dodecanal & $112-54-9$ & 0.003 & 0.0024 \\
\hline 18 & Benzothiazole & $95-16-9$ & 0.003 & 0.0005 \\
\hline
\end{tabular}


WHC-SD-WM-ER-425 REV. 2

\begin{tabular}{|c|c|c|c|c|}
\hline$\underset{\#}{\text { Cmpd }}$ & Compound & $\begin{array}{l}\text { CAS' } \\
\text { Number }\end{array}$ & $\begin{array}{l}\text { Average } \\
\left(\mathrm{mg} / \mathrm{m}^{3}\right)\end{array}$ & $\begin{array}{c}\text { Standard } \\
\text { Deviation } \\
\left(\mathrm{mg} / \mathrm{m}^{3}\right)\end{array}$ \\
\hline 14 & $\begin{array}{l}\text { Benzeneacetic acid, } a, \\
\text { 4-bis[(trimethylsilyl)oxy]-, methyl ester }\end{array}$ & $55334-40-2$ & 0.003 & 0.0027 \\
\hline 4 & Cyclotrisiloxane, hexamethyl- & $541-05-9$ & 0.003 & 0.0044 \\
\hline 3 & Hexanal & $66-25-1$ & 0.003 & 0.0054 \\
\hline 34 & $\begin{array}{l}\text { 2,5-cyclohexadiene-1,4-dione, } \\
\text { 2,6-bis(1,1-dimethylethyl)- }\end{array}$ & $719-22-2$ & 0.003 & 0.0017 \\
\hline 50 & 9-Octadecen-1-ol, (Z) & $143-28-2$ & 0.002 & 0.0031 \\
\hline 30 & Undecanal & $112-44-7$ & 0.002 & 0.0021 \\
\hline 46 & Alkane & & 0.002 & 0.0036 \\
\hline 15 & 2-Nonenal, (E) & $18829-56-6$ & 0.002 & 0.0038 \\
\hline 25 & 2-Nonanone & $821-55-6$ & 0.002 & 0.0032 \\
\hline 19 & Alkanoic acid and others & - & 0.002 & 0.0028 \\
\hline 37 & 2-Dodecanone & $6175-49-1$ & 0.002 & 0.0019 \\
\hline 36 & 2-Decanone & $693-54-9$ & 0.001 & 0.0013 \\
\hline 35 & Alkanol & & 0.001 & 0.0018 \\
\hline 38 & Decanoic acid & $334 \sim 48-5$ & 0.001 & 0.0016 \\
\hline 39 & Hexadecanoic acid & $57-10-3$ & 0.001 & 0.0020 \\
\hline 21 & 3-octene & $592-98-3$ & 0.001 & 0.0013 \\
\hline 20 & 2(3H)-Furanone, dihydro-5-propyl- & $105-21-5$ & 0.001 & 0.0012 \\
\hline 42 & 1-Hexanol, 2-ethyl- & $104-76-7$ & 0.001 & 0.0011 \\
\hline 29 & 5,9-Undecadien-2-one, 6,10-dimethyl-(Z) & $3879-26-3$ & 0.001 & 0.0023 \\
\hline 26 & 2-Octanol & $123-96-6$ & 0.001 & 0.0012 \\
\hline 45 & Decane, 4-cyclohexyl-, 4-cyclohexyl- & $13151-75-2$ & 0.001 & 0.0012 \\
\hline 31 & Benzenamine, $n$-phenyl- \& others & & 0.001 & 0.0026 \\
\hline 47 & 9-Octadecenoic acid, (Z)- & $112-80-1$ & 0.001 & 0.0015 \\
\hline 12 & Phenol, 2-methyl- & $95-48-7$ & 0.001 & 0.0026 \\
\hline 49 & 1-Octadecene & $112-88-9$ & 0.001 & 0.0011 \\
\hline 28 & Dodecanal & $112-54-9$ & 0.001 & 0.0011 \\
\hline 11 & Ethanone, 1-phenyl- & $98-86-2$ & 0.001 & 0.0023 \\
\hline
\end{tabular}


WHC-SD-WM-ER-425 REV. 2

\begin{tabular}{clccc}
\hline $\begin{array}{c}\text { Cmpd } \\
\#\end{array}$ & Compound & $\begin{array}{c}\mathrm{CAS}^{1} \\
\text { Number }\end{array}$ & $\begin{array}{c}\text { Average } \\
\left(\mathrm{mg} / \mathrm{m}^{3}\right)\end{array}$ & $\begin{array}{c}\text { Standard } \\
\text { Deviation } \\
\left(\mathrm{mg} / \mathrm{m}^{3}\right)\end{array}$ \\
\hline \hline 27 & Phthalate & & 0.001 & 0.0014 \\
10 & $1-$ Octanol & $111-87-5$ & 0.001 & 0.0023 \\
54 & 1 -Hexadecanol & $36653-82-4$ & 0.001 & 0.0025 \\
55 & $16-$ Methylheptadecanol-1 & & 0.001 & 0.0025 \\
\hline \hline
\end{tabular}

1 Chemical Abstract Service.

2 Average of 3, 2-L samples, values listed are estimates. 